(1) 簡陚

\title{
國內之 部
}

\section{自然科學}

\section{1 䦥詠川等製造装備電子管}

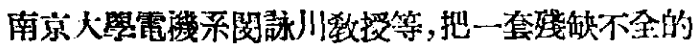

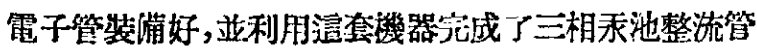
（電子管中的一種）的修理工作。

造種技術和原料，一向仰給外國，賞動手装置時，需

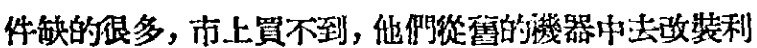

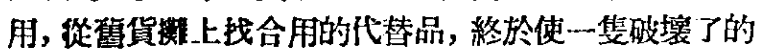
三相祕池整流管復活了。

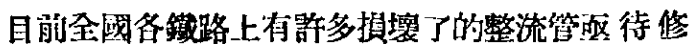

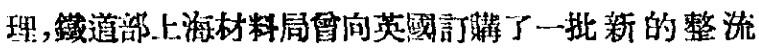

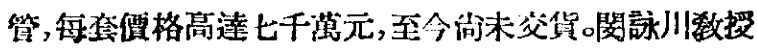

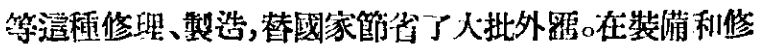
理湢程中，烡東数育部並撥專款二千元百萬元，作䉆添 製材料和研究之用。（南宗新菲日報 3月15日）

\section{2 南大助数姚崒試製金相㙷微 鏡成功}

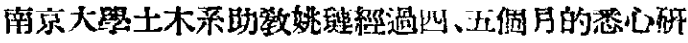

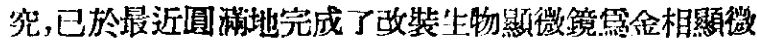

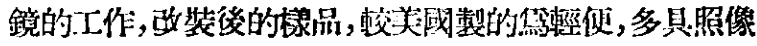

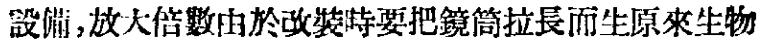

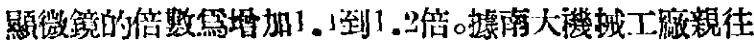

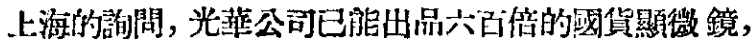

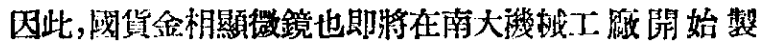
造, 且已接到華東工業部的訂貨詢問, 正洽訂合同中。

\section{(文蹈報 3月13日)}

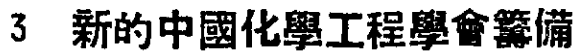 會已成立}

該會由㕠的中國化學工程學會, 與中華化學工業會

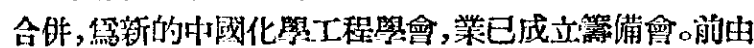

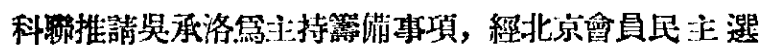

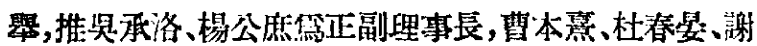

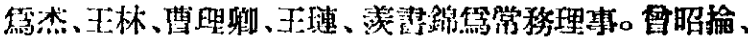

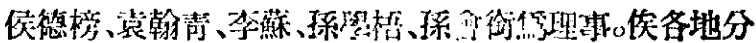

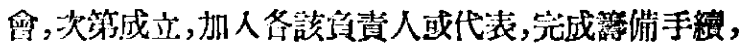
存於本年夏间了，参加科聯所召集的备專門工程照會聯合 代契年會，或分別舉行年會，正式成立。

(吳乘洛)

\section{9 法國鐳鉈學院瞺我廈門大學 放射性藥品一批}

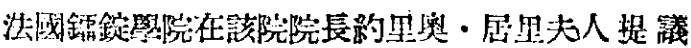

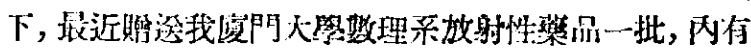

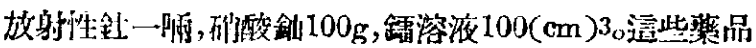

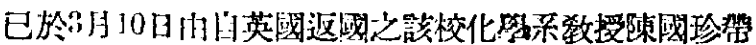

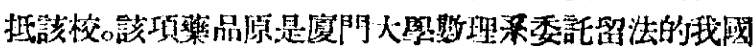

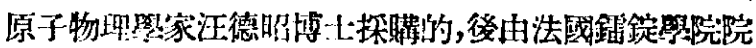

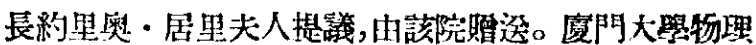

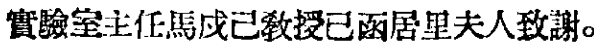

$$
\text { (新華社稿 } 3 \text { 月23日) }
$$

\section{5 生理生化研究所的新研究}

生理生化研究所, 在研究桶微素時, 最近求得一種

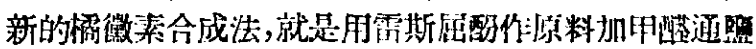

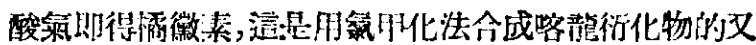
一例。

（本院:工作閔報）

\section{6 疽陽縣發掘史前冰期古生物 遭骨}

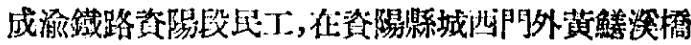

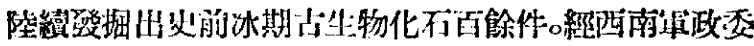

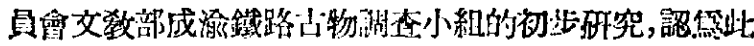

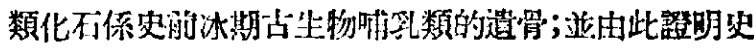
前四川盆地䉆冰川所細之處。

（新華社稿 4 月12日）

\section{7 水生生物研究所半月之工作 近况

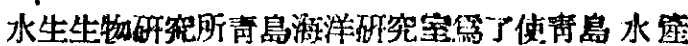

第五期 


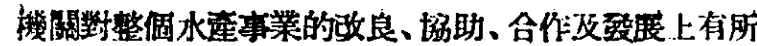

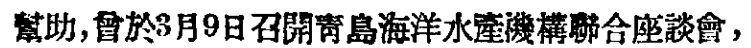

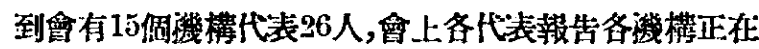

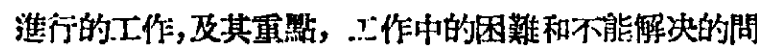

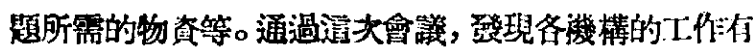
很多相同和需要配合的地方。笉了加强彼此的距系與了 解, 决定船常舉行“青島海洋水座㙨構距合座談會”, 由

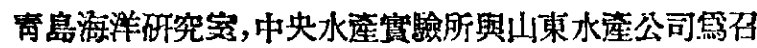
集機蔽。

（本院工作間報）

\section{8 中國科學院召集會議討論苜 種保藏問題}

3月19日下午科隄院在院本部召集北京工業試

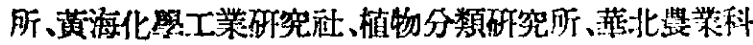

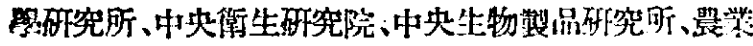

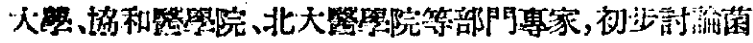

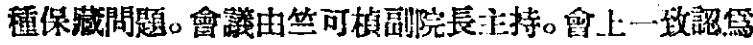
過去菌種係由各單位目行保藏，彼此沒待聯系，交換菌

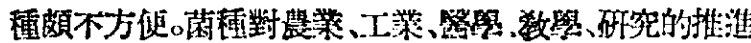

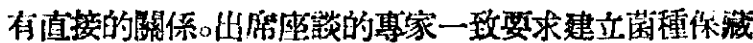

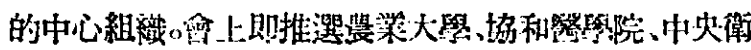
生研究院、中央生物製品研究所、菜北留業科思研究所、

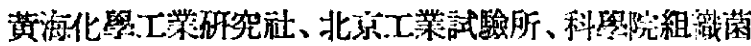

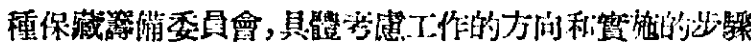
等問䫛,並與全践有關方湎淮行胘系。

(光明日嘏 3 月26日)

\section{9 的北發現漂白土磷}

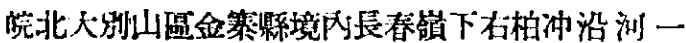

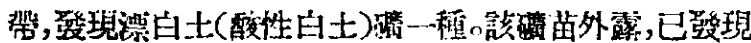

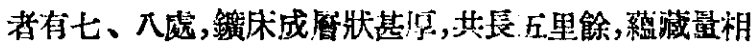
當豐简。

(化思此界 6卷期)

\section{0 北大地雷系張俩㨬数授改装 反光偏光顯微鏡成功}

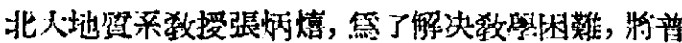

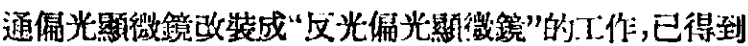

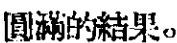

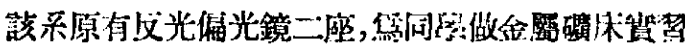

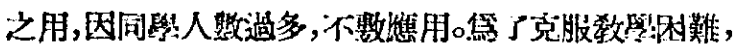

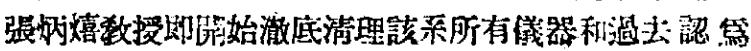

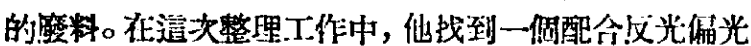

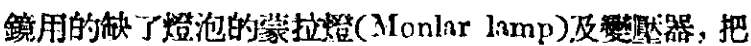

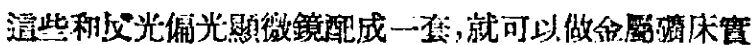
榃之用。

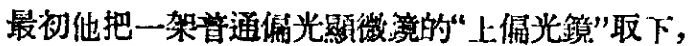

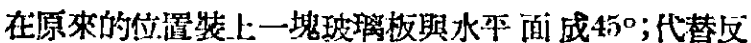

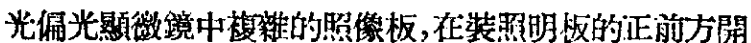

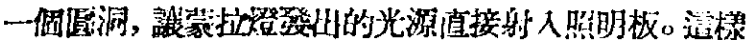

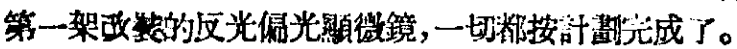

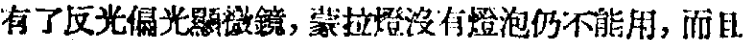

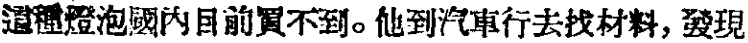

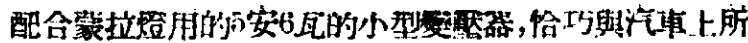

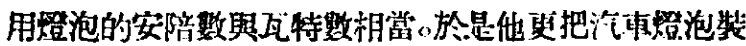
在蒙拉短上，梁然得到了預期的效果。

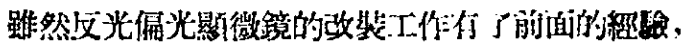

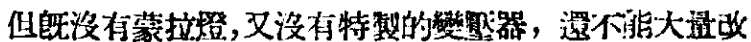

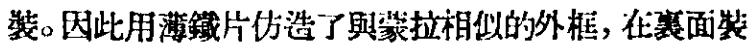

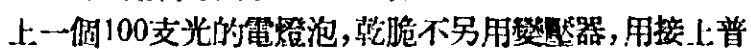
通電燈的電源。但是用造種燈光發出的光源的人照明

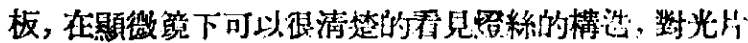

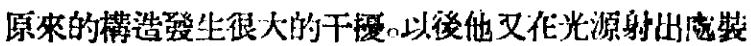

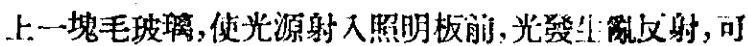

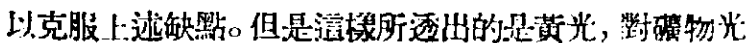

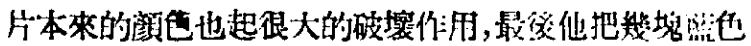

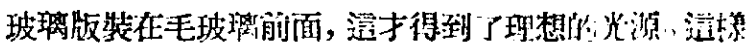

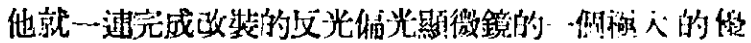

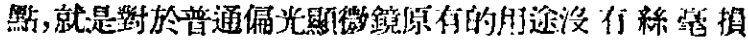

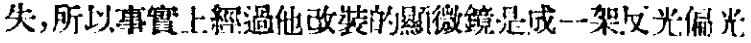
兩用憼微管。

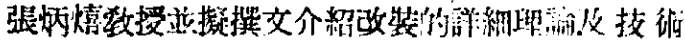

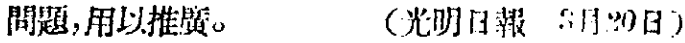

\section{1 中南地貢調查所成立}

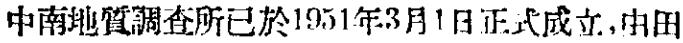

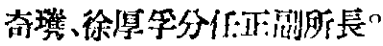

(排)

\section{2 有關黄河的統計数字}

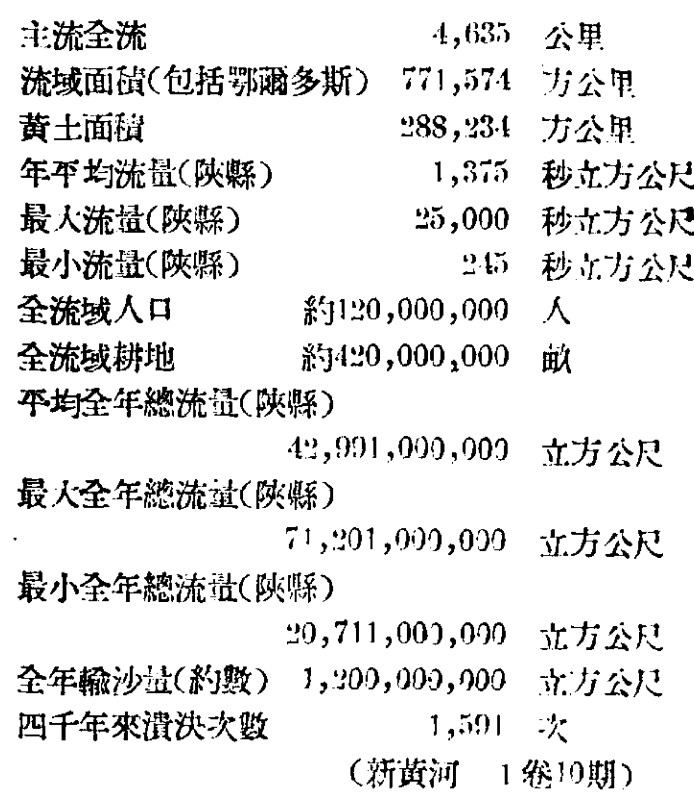

\section{3 地理研究所在京召開第三次} 簏委會

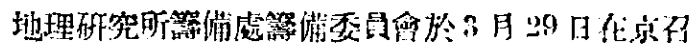

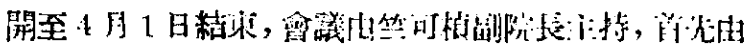

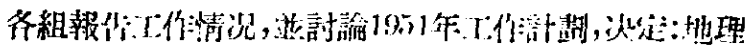

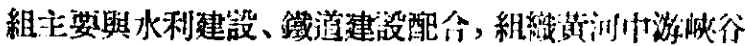

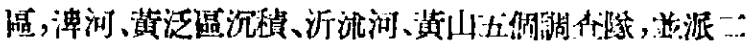

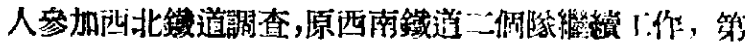




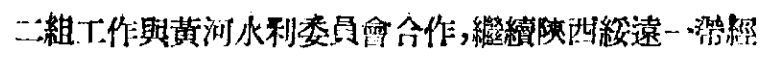

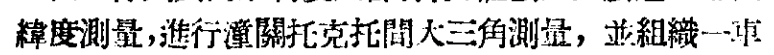

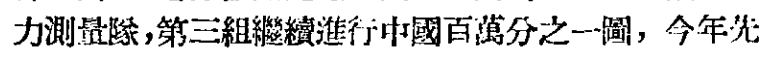

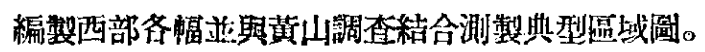

（本院工作簢報）

\section{工歯科學}

\section{4 勞模張德慶創造代用機油}

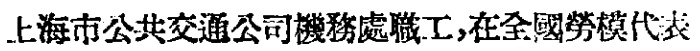

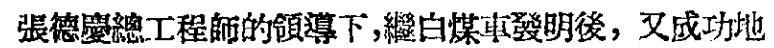
創造了一種以植物油代用機油。代機油的品犋和功用超 過美貨德士古 30 號油，成本低於德士古油。現会交修峾

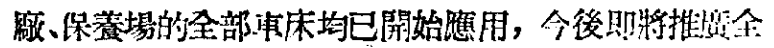
面應用。

(文䠰報 3 月ะ3日)

\section{5 常帅勞動模範朱玉生創造火 筷焠火法}

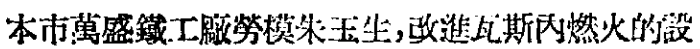
诵,創造了火筷悴火法。克服了部份焠火的团䧼; 而且能

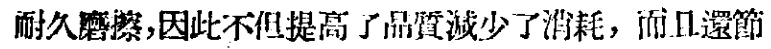
省了很多工特。提高了發火力, 克服了過法嘜工多受潮

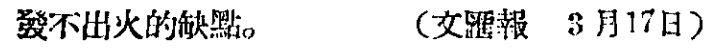

\section{6 吳凱申製造鎆絲錄晋機成功}

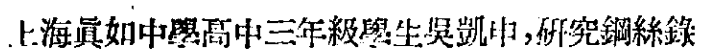
普機的製选，已倠得成功。(淈大公㘧 3 月19日)

\section{7 江南大學技術員李叢研究“萬 用汽燈"'成功}

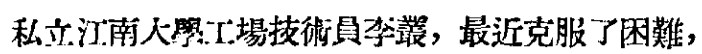
呼究“萬时汽登”已獾成功。

“萬肋汽燈”的模浩，主要是一储正油简抱着一個副

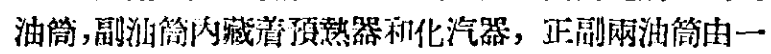

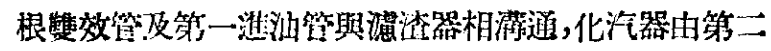

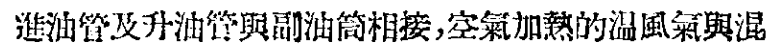

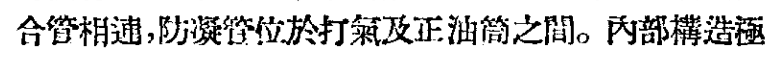
墨精緶靈巧。

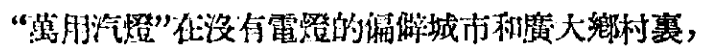

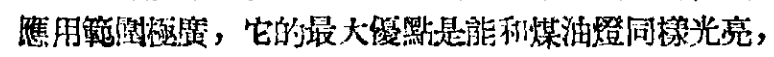

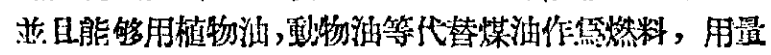

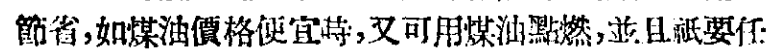

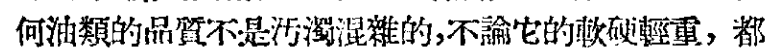

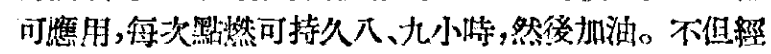
濟望惠，而且製造漂格漫比煤汽燈侹宜。

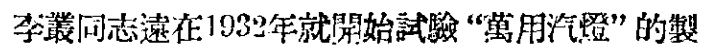

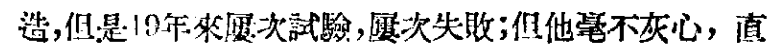
到今天，方子克服條件隹三和環境的限制等重重困難,

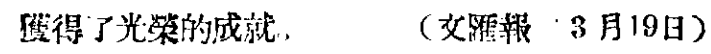

\section{8 浙江大學落加治淮同學創造 測量新法}

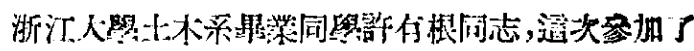

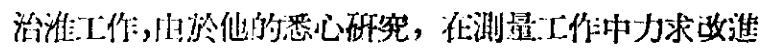

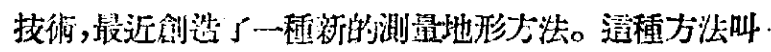

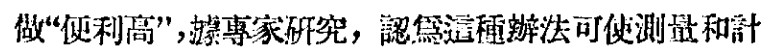

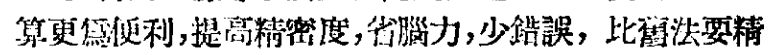

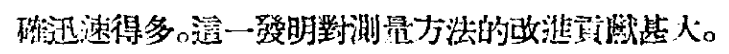

(文罷赫 3 月16日)

\section{9. 國斯字棉紡製60支紗成功}

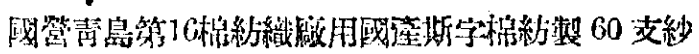

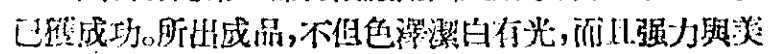

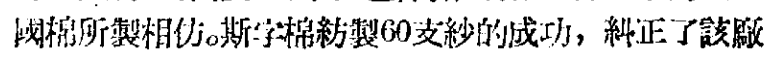

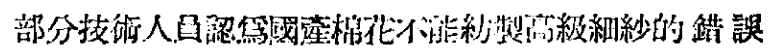

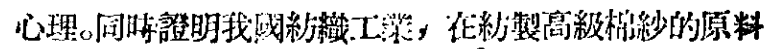

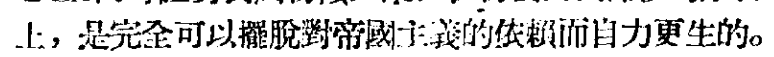

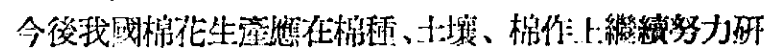

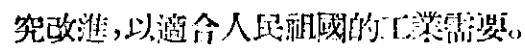

$$
\text { (人民甘赧 } 3 \text { 月18日） }
$$

\section{0 唐山鋼鐵廠連創三次新紀錄}

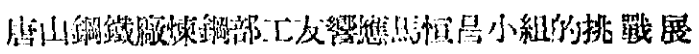

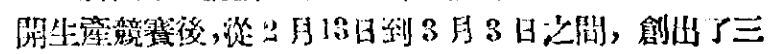

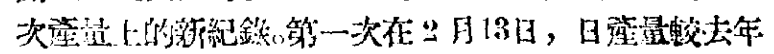

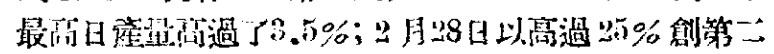

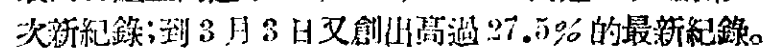

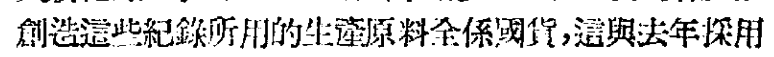

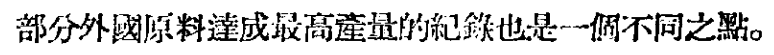

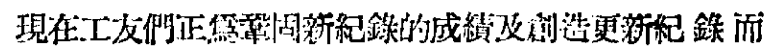
繼續努力。

(人民日報 3 月18日)

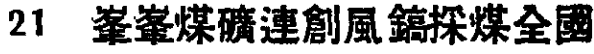 新紀錄}

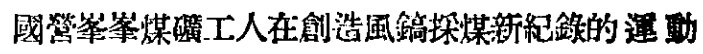
中,趙交信小組以 243 㗅打破了淮南煤露 2月25日陳玉

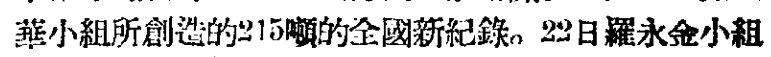
又創造:254.4噸的更新紀鉨。

在趙文信小組㓣造全國新紀銑以後,該磷正㓭局長

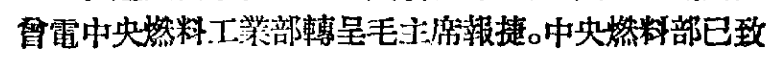

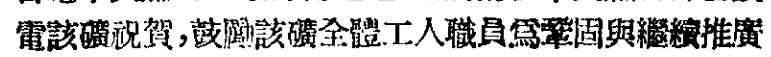

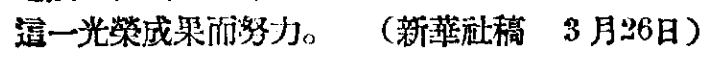

\section{2 四川樂山鐵碃可露天開探}

樂山專署因奉上，級指示，攻脽工業为面的需要，要

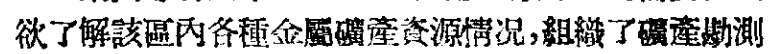

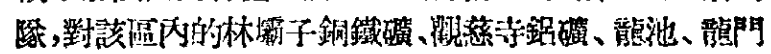

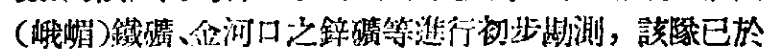

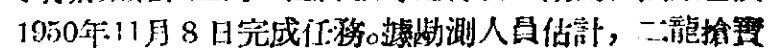

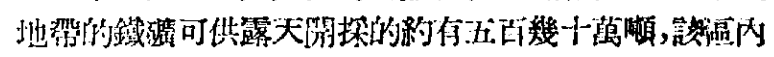

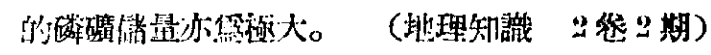




\section{3 湘桂駖鏻路來兴南窂段已通車}

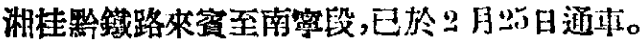

(人民日報 3 月15日)

\section{4 湘桂線柳䍃段修竣通車}

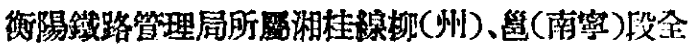

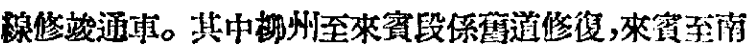

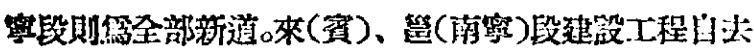

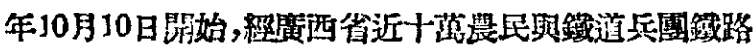

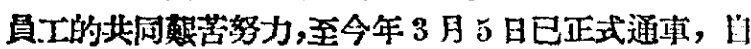

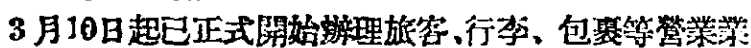

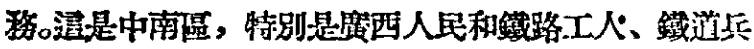
團，在抗美援朝的新形勢與全國勖政殌沾情况份末基本

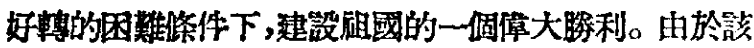

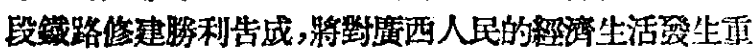
装的良好影繁。

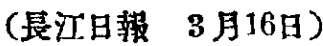

\section{5 綏遠安全渡迢黃河凌汎}

自3月24日開始,黄河上游部分開体,河水速同水坮

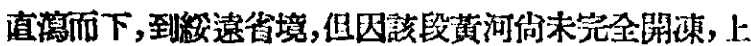

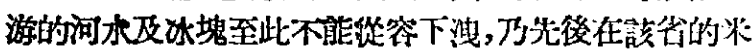

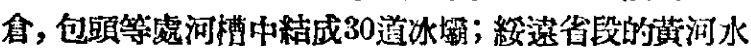

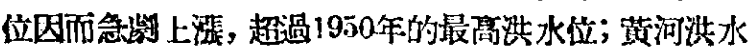

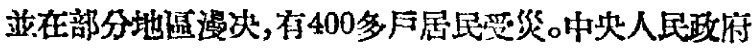
閏訊以後,即於4月1日派飛楼设人民解放軍某部砲兵

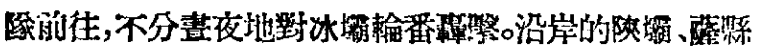

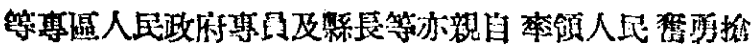

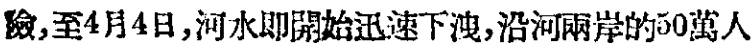
民和百多苚族食田矣受水災。

\section{（光明日趣 4 月12日）}

\section{6 兴河下游塂口工程竣工}

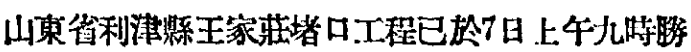
利完工。該虎黄河堤防在今年2月3日因凌沉决口，常特

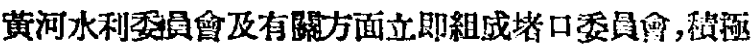

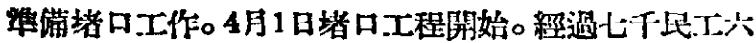
天六夜的緊張工作挠，於4月7日晨脐利完工。沿河民工

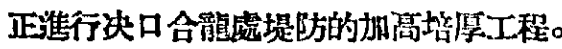

\section{(新薄鸪稿 4 月11日)}

\section{7 春季治淮工程已全面開工}

根洽淮河的 1951 年春季工程，除熟洪工程中的部分 技微性工程外，其食余工程現已全面開工。河南、皖北、蘚

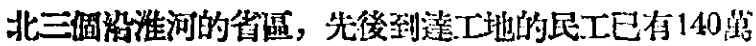
人。大批的工程器材和工具, 现正淡全國各地源源湩徍 淮河.工地。現在淮河中游晥北各地的復堤和疏浚河道等

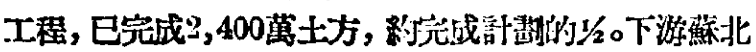

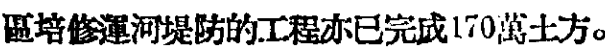

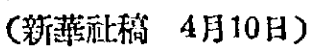

\section{8 荆江大嚗已完成110穊萬土方}

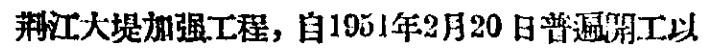

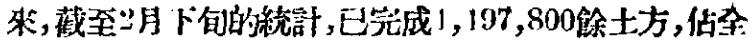

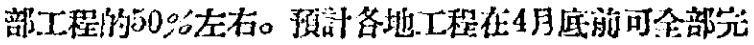
成。

$$
\text { (長江日赫 } 3 \text { 月20日) }
$$

\section{9 淀北區工程已開工 ～}

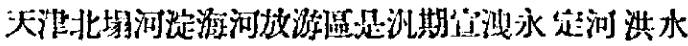

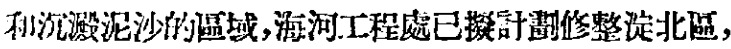
工程已於1951年3月20日閶工。

\section{（進步口赫 3月20日）}

\section{0 新邀硫勒興修英五斯坦馬場 水庫}

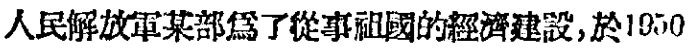

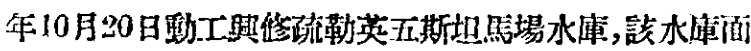

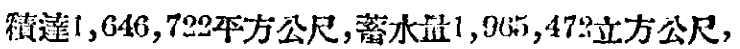

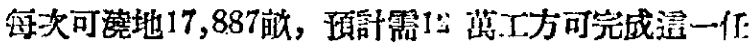
洛。

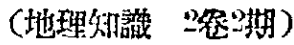

\section{1 新疆大力趕修紅雁池蓄水庫}

新各水力同决年目 1950年9月1日起至105\%年3月底

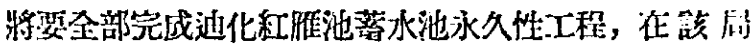

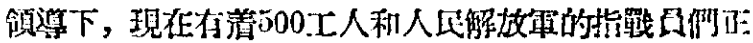

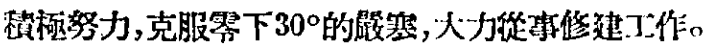

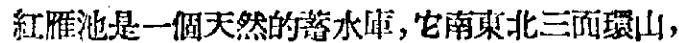

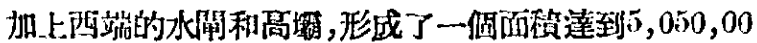

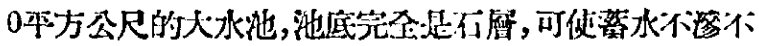

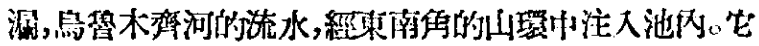

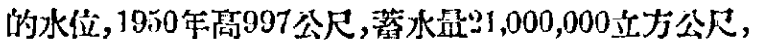

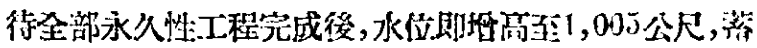

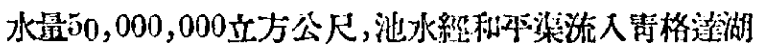

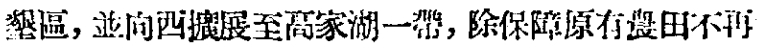

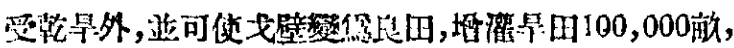

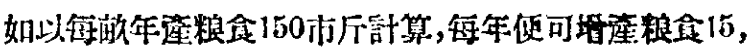
000,000 市厅 厂 $^{\circ}$

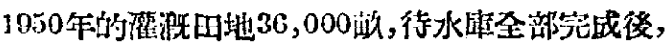

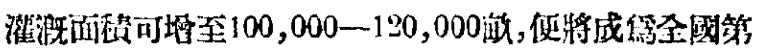
二入著水注(第一在台椤)。

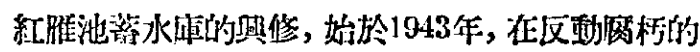

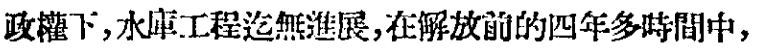

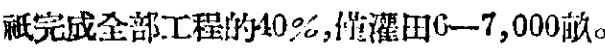

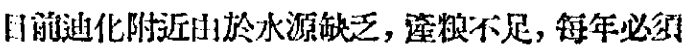

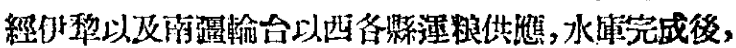

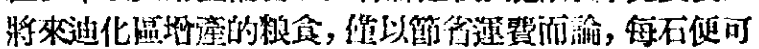

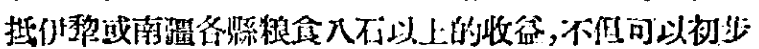

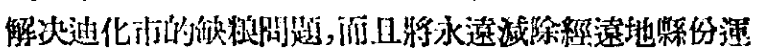

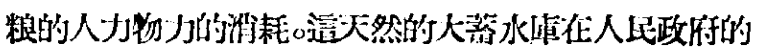

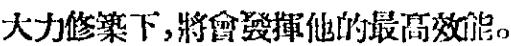

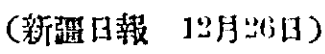

\section{2 全國各校航空柔會議閉幕}

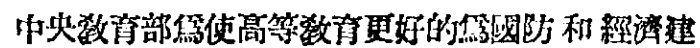




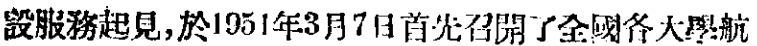

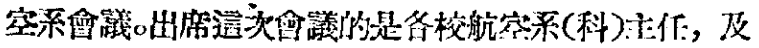

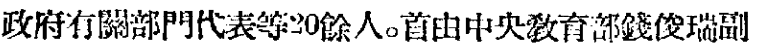

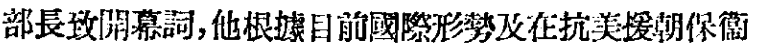
祖國的前提下提仙培善國防及經濟建設的幹部是中央

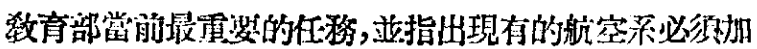
以調整、暂国與發展。把培養航空工程幹部與建設现代

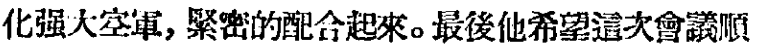
利成功第今後其他院系铜整與整頓，開出一條很正確的 道路。

\section{（光明日報 3 月31日）}

\section{3 全國水文、勘測會議閉幕}

中央人民政府水利部於 3 月 20 日在北京召開的全國

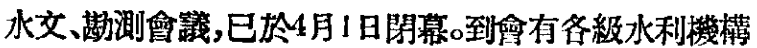
和中央人民政府有關部門代表，和大學郄授、專家等共1 10多人。

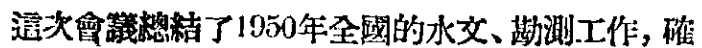

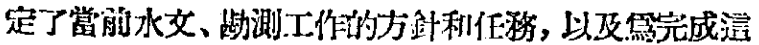
一任務而必須建立的工作例度。

\section{(新萧注稿 4 月4日)}

\section{農業科學}

\section{4 監水選種}

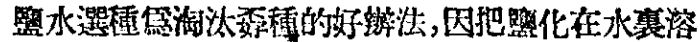
成鴊水，它的漂浫力此浮水大的多。若把種子放入淮去

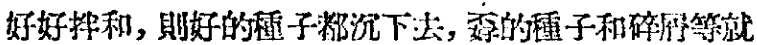
会漂在水面上; 把上面漂浮的東酒撤去, 將沉下的種子

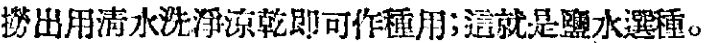

鼠水選種兄於種子的不同，用的分量也不一棣，現 把賞月用的照水介紹於下：

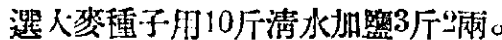

選小整種子用 10 斤清水最少加盃 3 斤 2 兩。

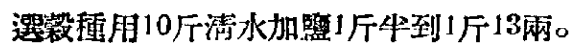

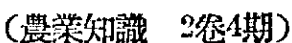

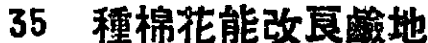

棉花根哚拔险，種上㑈年棉，战性一年能比一年整， 也就省工了。但是溜注意多施肥，佊地不要上草木灰(柴 灰，小灰），人瓷尿等含检性大的肥料。多上草脚瓷、士

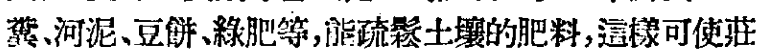
稼長的好。

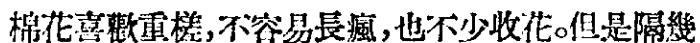

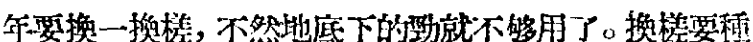

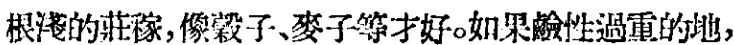
可以在伏天種苗落, 兩三年後就诣變成好地了。

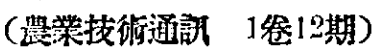

\section{6 海南岛的淥膠樹}

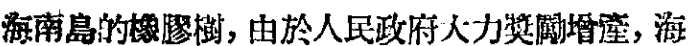

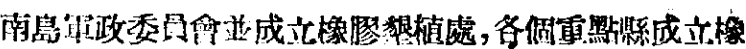

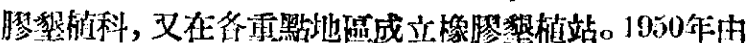

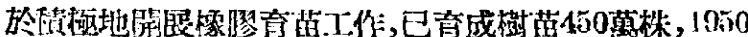

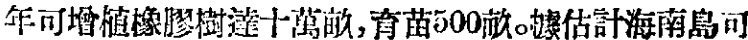

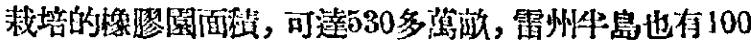

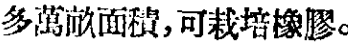

（人民日報 3月24日）

\section{7 分枝小麥每的收權一千一百斤}

焦生筧同志，他是平原修武縣三隄新安錤人，他巴 是50馀蔵，富存㻃郝經驗的老農，他栽培的分枝小麥每 确能打 1,100 斤。

(軷訊 No.40)

\section{8 夏至麥}

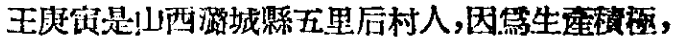

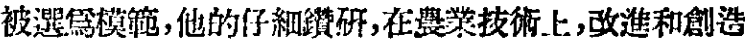

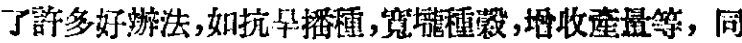

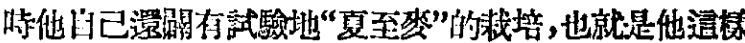

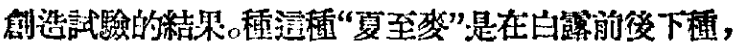

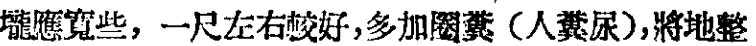
鬆些,它就能長好的。到寒露時, 就有收成了。

(䊦訊 $\left.\mathrm{N}_{0} .40\right)$

\section{9 西南各地開展護林、造林工作}

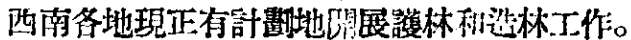

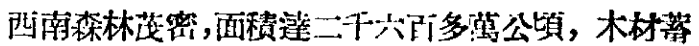

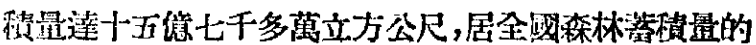

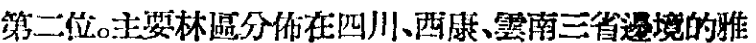

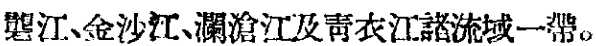

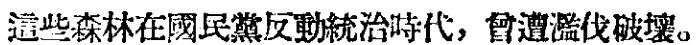
西南解放後，人民政府非常注意保镜森林。四南隺政李 員會兽於1950年12月到1951年3月間，光後預發了有閔

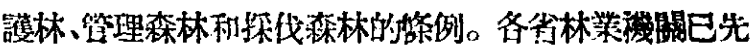

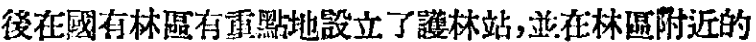
攷、錤、村成立了護林委員會或踓林小組。現㮖西康、贵

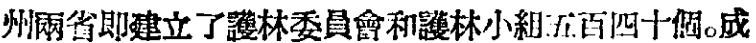

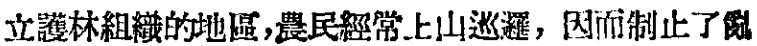
伐林木、鈨山和不法地主破燷森林的活動。

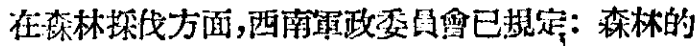
年探伐量，以不超過森林年坐長量经原則; 凡大棁模的

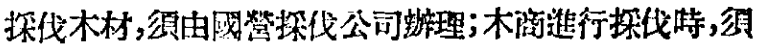

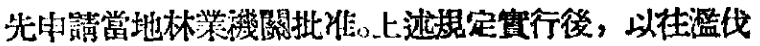
林木的現像已基本上滑除。

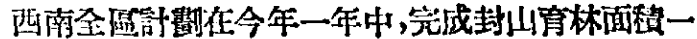

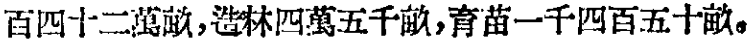

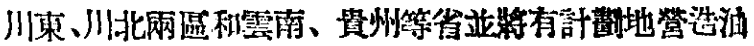

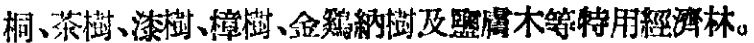

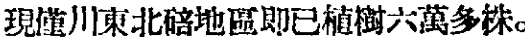

(新藏社稿 3 月20日) 


\section{0 東北小麥，水稻，大豆的技 術合䜅}

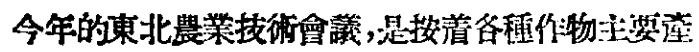

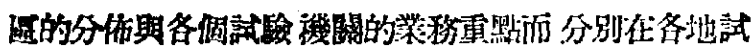

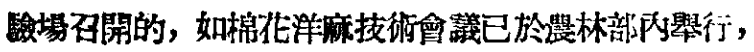

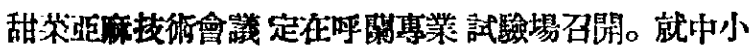
桨、水稻、大豆三種作物的技術會蟻於 3 月5日起在公主

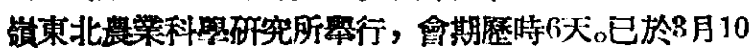
日圆确閉盘。

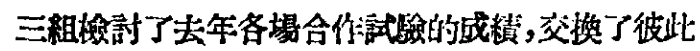

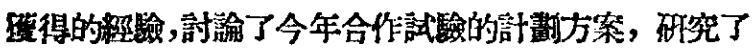

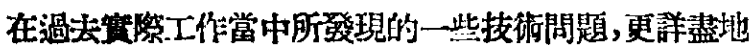
研究討論借訂了由東北隻 栄科學研究所所起草的造三 调作物的今後東北較長時期(初站訂第10年)的育種、栽

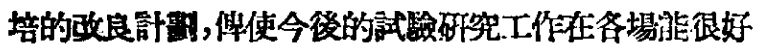
的分工合作，以發揮最大的作用，而共同來完成東北的 费業政進工作。

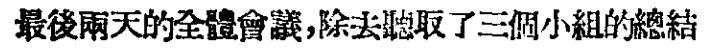

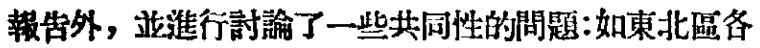

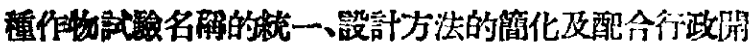

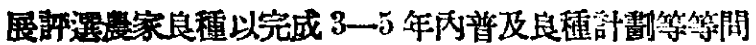
題，程過熱烈地討論都瓁得了初步的結論，除部份材料

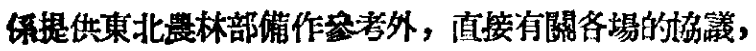
各堨都表示在今年一定要開始貫澈執行。

(農業技街通訊1兔(2期)

\section{1、湖南大學串學院與湖南省立 数業重科學校合併成湖南廐 學院}

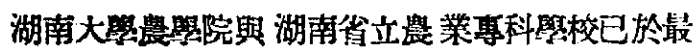

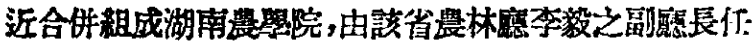

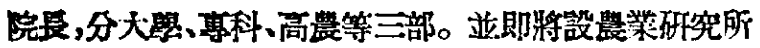

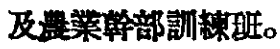

(長江日報 3月23日)

\section{2 孫曉帓任患大校長}

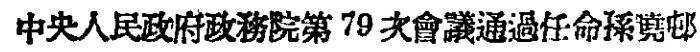
馬北京䍔業大學校長。

(光明日報 4月11日)

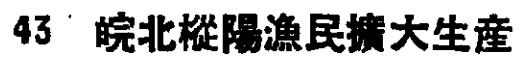

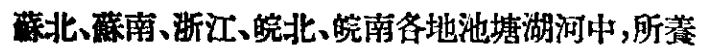

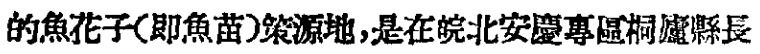
河流入長江口的格陽頡。

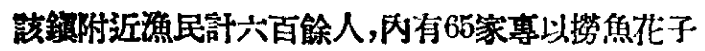

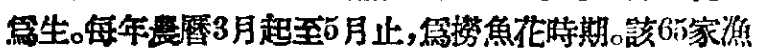

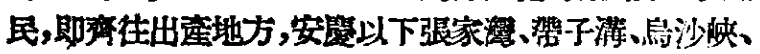

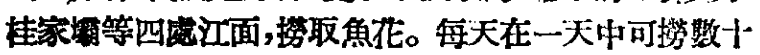

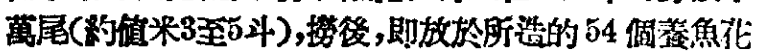

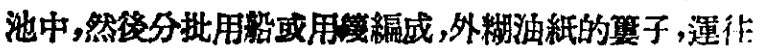

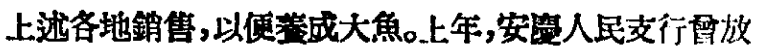

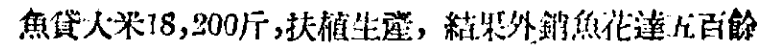
萬尾, 獲利米四滺飻厅。

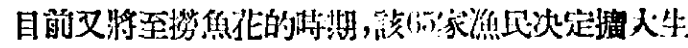

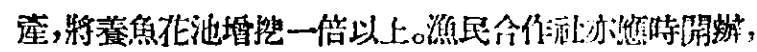

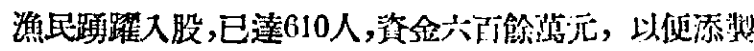

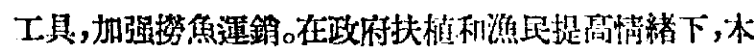
年魚花生和唯利,定可超過上年。

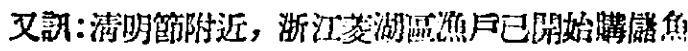

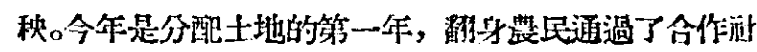

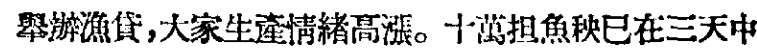
競贈一空,現在等待第二批運到。

$$
\text { (大公報 4月5日) }
$$

\section{䜿藥街生}

\section{4 馬金堂贀師㓣製螢光片和觀 察燈}

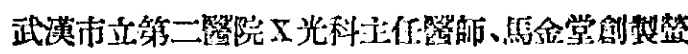

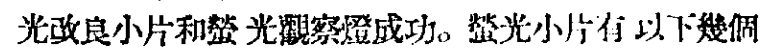

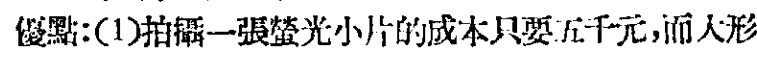
的X光片則需入蕰元。(2)每三分鎲可拍虂一人，提高了

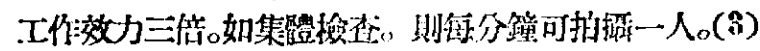
比美製3.5公分䀆光片大八倍，易於䘽察。(4)侮張小片， 只有入公分長，六公分筧，比校寉易悺藏。

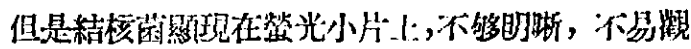

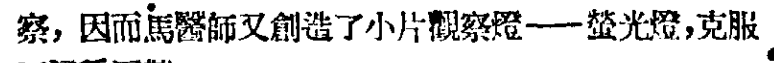
了䒸種困蜼。

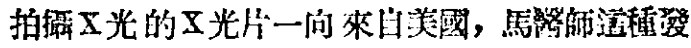

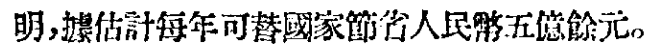

(北京工人日赫 2 月15日)

\section{5 長春市立醫院眼科試用組䋍 療法成功}

長春市立登院服科，從去年7月就試用“組織潦法”，

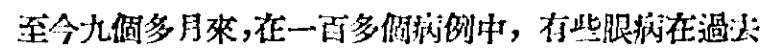

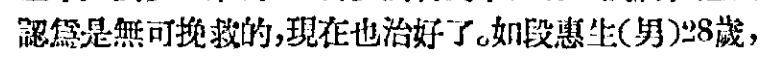

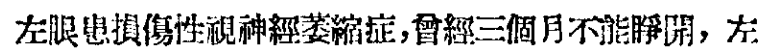

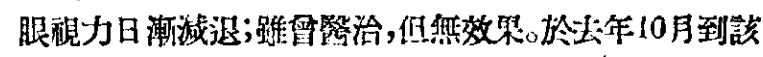

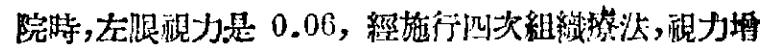

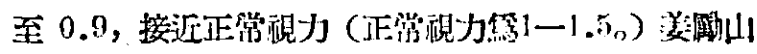

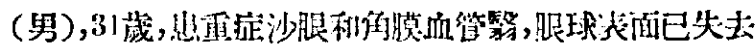

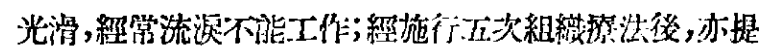

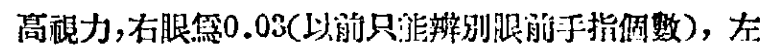

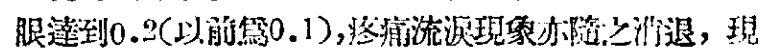

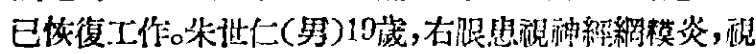

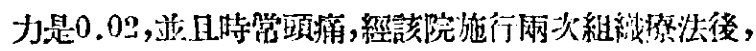

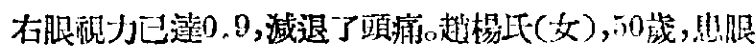

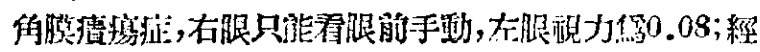

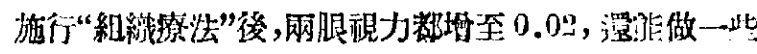
針線活。 


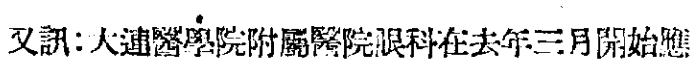

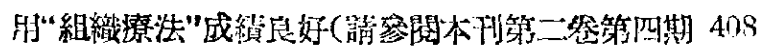

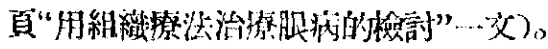

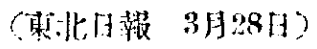

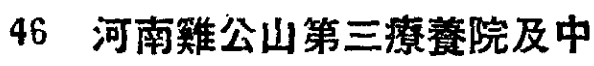 南軍區某療養院試用組織療 法均槚良好成綪}

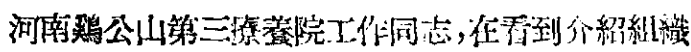

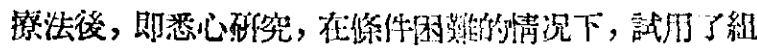

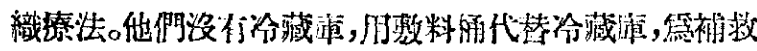

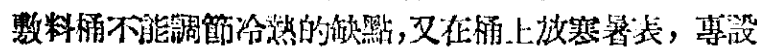

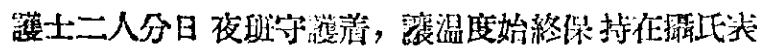

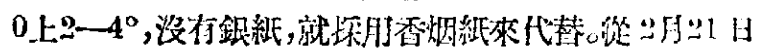

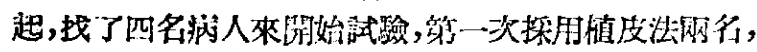

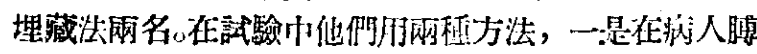

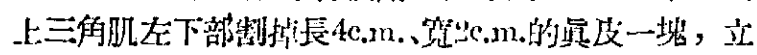

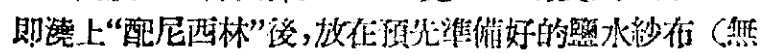

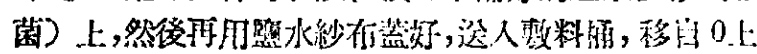

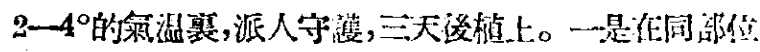

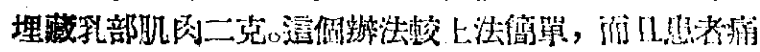

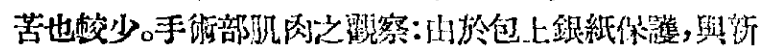

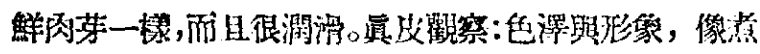
熟的网一桹。

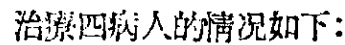

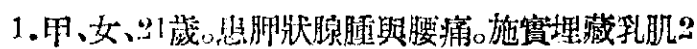

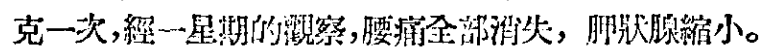

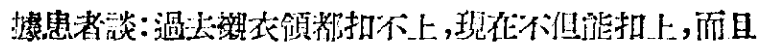

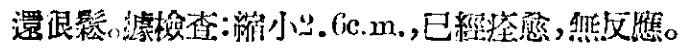

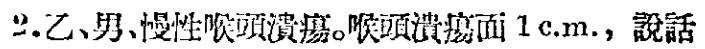

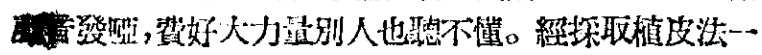

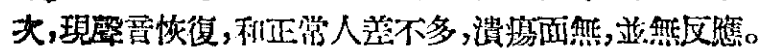

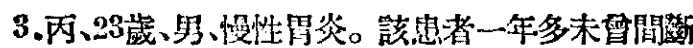

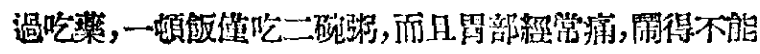

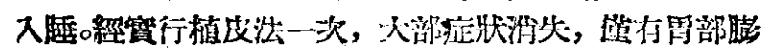

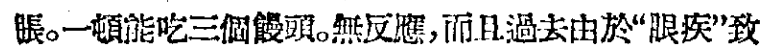
限發旨，現在眼睛感到發完而刭楚。

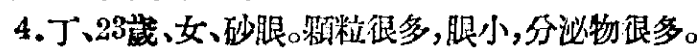

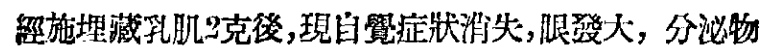

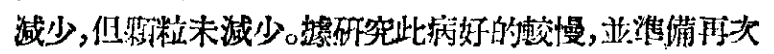
施手衍, 然反政。

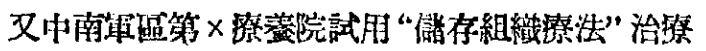

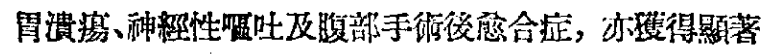
功效。該院於本年1月16日、2月11日先後給 10 名病虽施

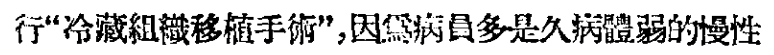

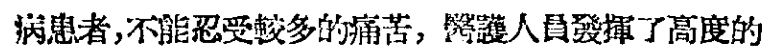
階級同情心，在他們自己身上㓡取“組織片”，給流員移

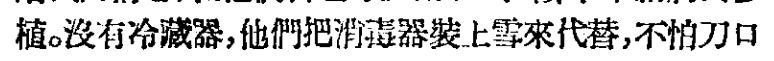

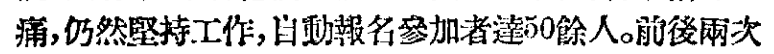

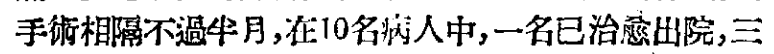

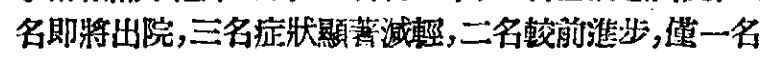

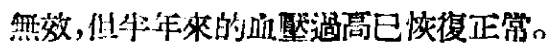

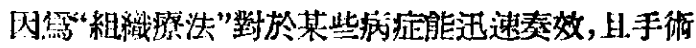

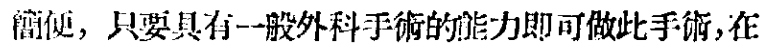

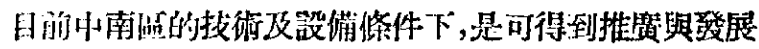

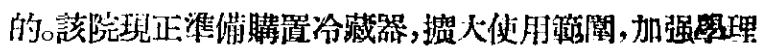

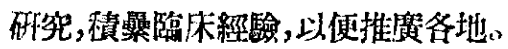

$$
\text { （長江日報 3月16日） }
$$

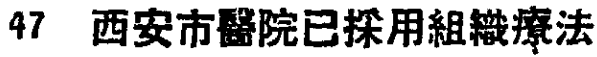

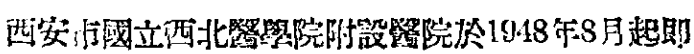

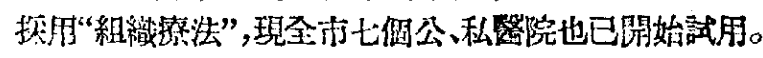

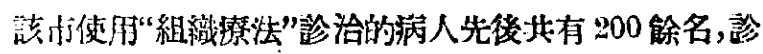
治的效果良好。

(新華社稿 4 月8日）

\section{8 中國紅十字總會醫防服䅂大 榢又有一批醫務工作者赴治 淮區工作}

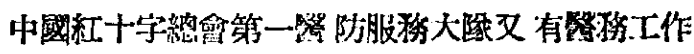

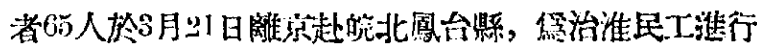

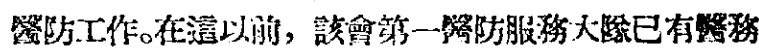

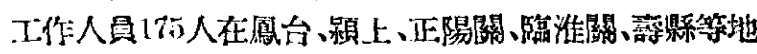

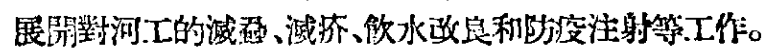

(新華社稿 3 月23日)

\section{9 江西离諓縣衛生工作者協會 配合土改組成醫療隊下鄉}

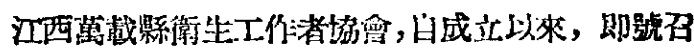

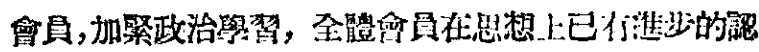
識,該會發野會員保障土改運野幹部的煡康，組成士改

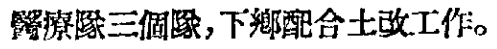

(武漢科囬通訊 No.11)

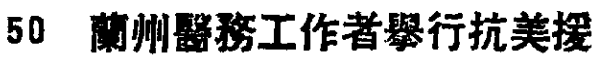 朝示威遊行}

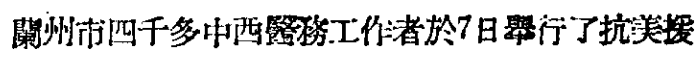

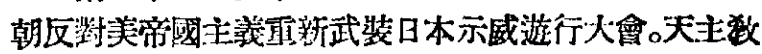

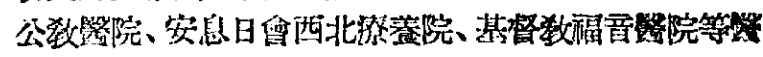

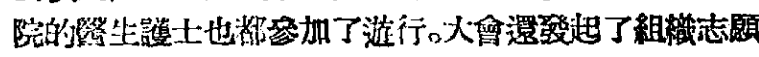

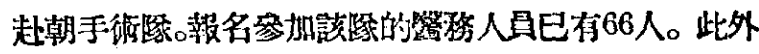

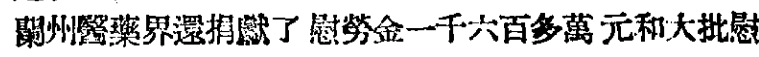

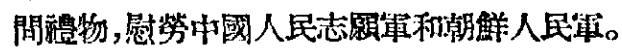

(光明日報 4月10日)

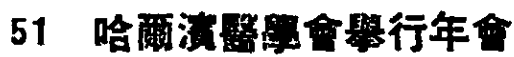

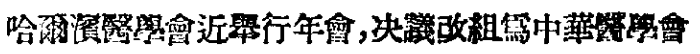
哈爾濱分會。會上立有專题報告: (1)巴甫洛夫的高級神

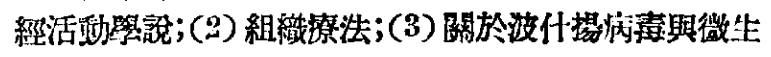

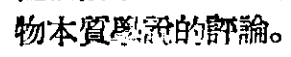

(光明日報 3月19日) 


\section{2 中央衛生部弡出“春季防疫 指示”}

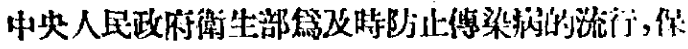

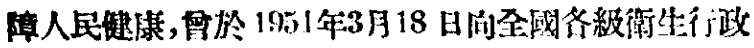

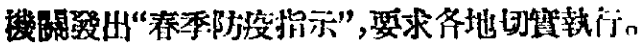

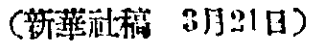

\section{3. 中南各省展開畜疫防治工作}

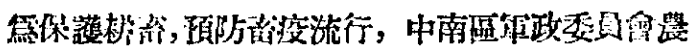

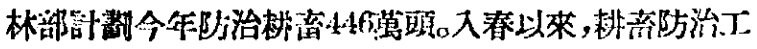

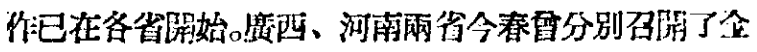

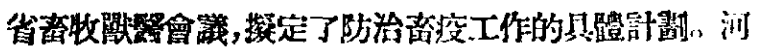

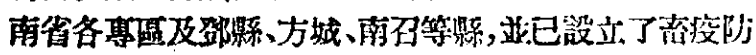

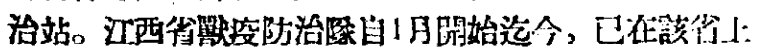

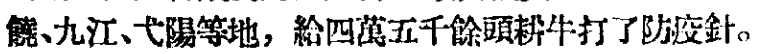

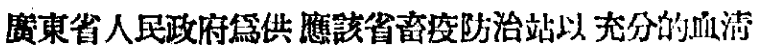

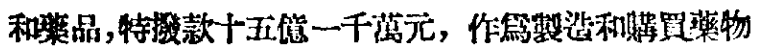

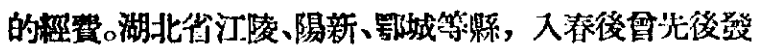

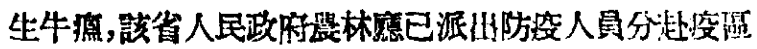
救治。

(新華社稿 3 月16日)

\section{社會科學}

\section{4 中央人民政府等備組臷中南 各民椟訪問圈}

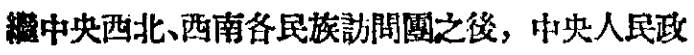

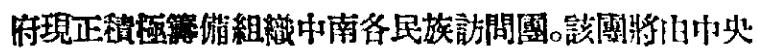

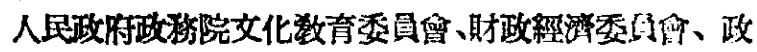

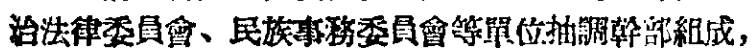

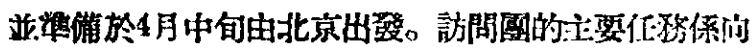

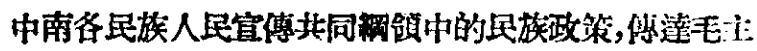

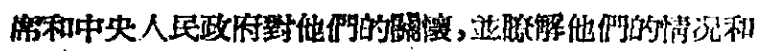

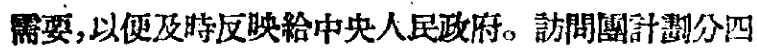

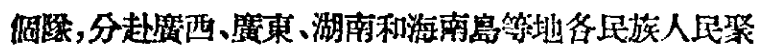

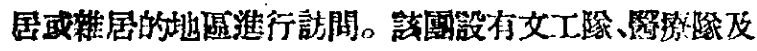

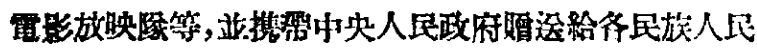
的人批福物。

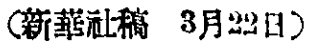

\section{5 繁学通任民族學院副院長}

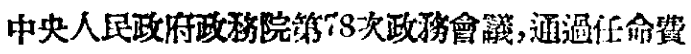

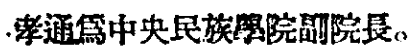

$$
\text { (光明日報 4月11日) }
$$

\section{6 江害湖熟鎍發現史前遗址}

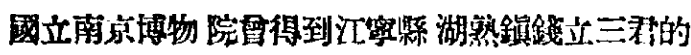

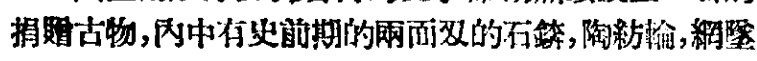

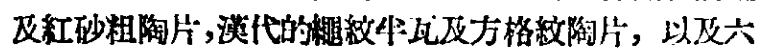

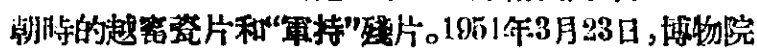

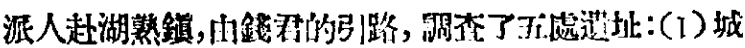

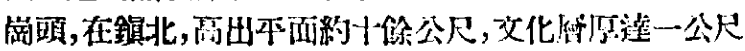

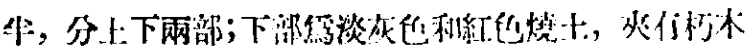

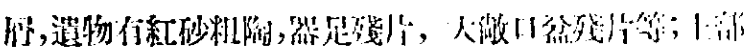

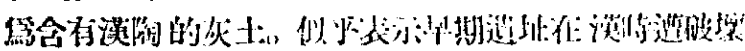

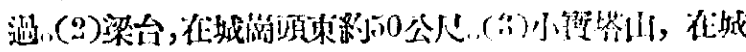

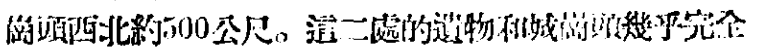

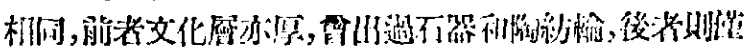

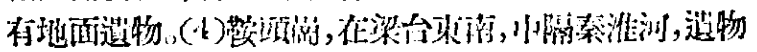

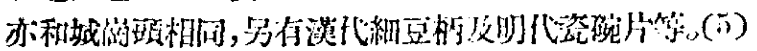

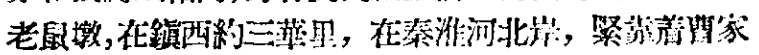

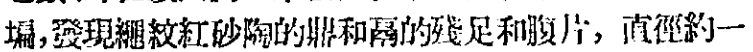

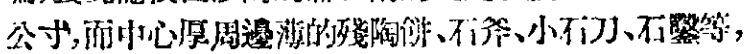

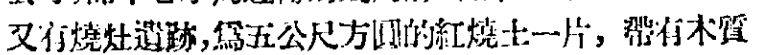

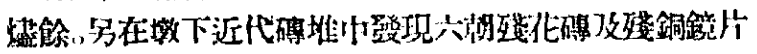
济一塊。

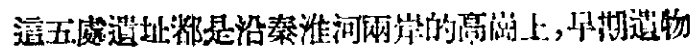

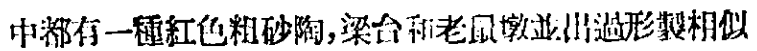

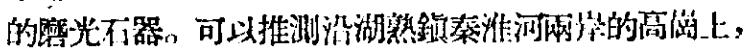

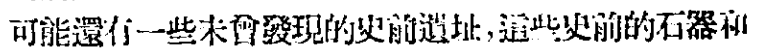

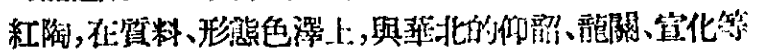

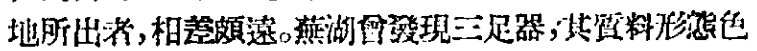

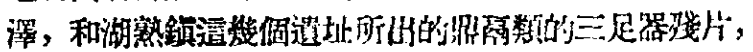

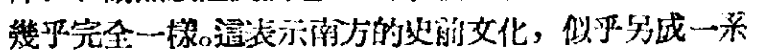

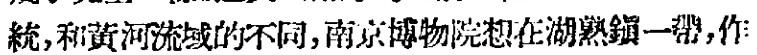
進一步的調查，然挠展開發倔.工作。

\section{(国立献宗栝物院)}

\section{7 內江憬連續弡現三座漠代古墓}

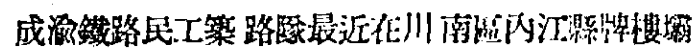

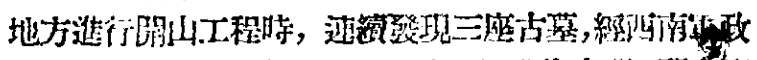

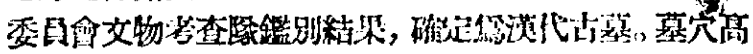

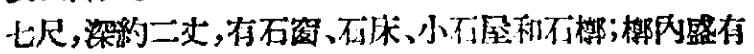

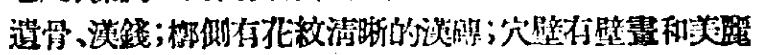

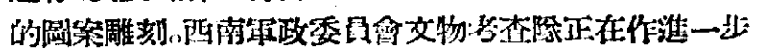
的發擗和。

(新蕉酒稿 4月9日)

\section{8 教究太平天國䢖靕南京有二 重要發現}

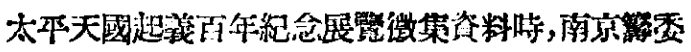

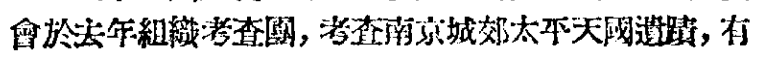

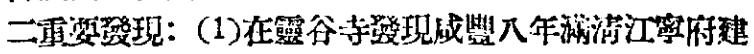

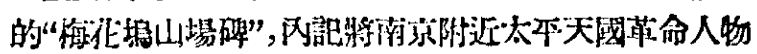

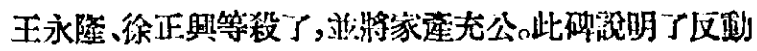

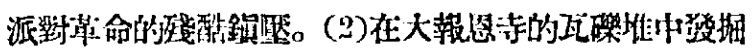

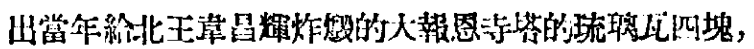

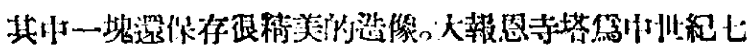

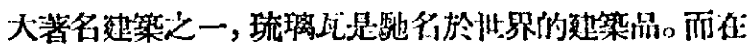

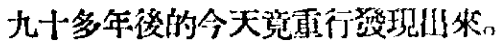

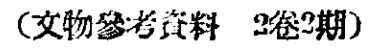

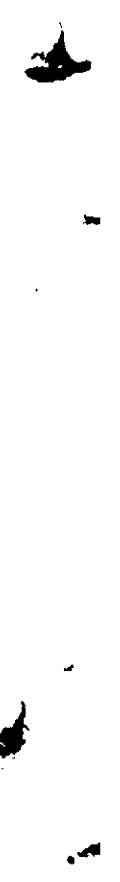




\section{9 安徽省綪溪縣弡現太本天國 攻城壁畫}

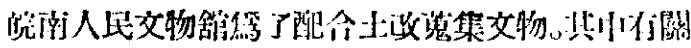

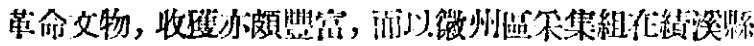

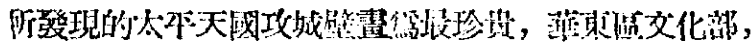

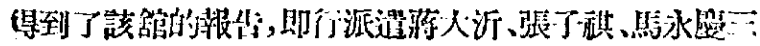

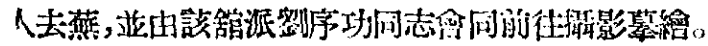

（光明日報 4 月5日）

\section{0 北京文物整理委員會組織文 物勘查組赴山東工作}

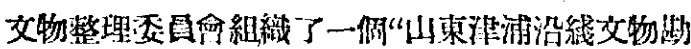

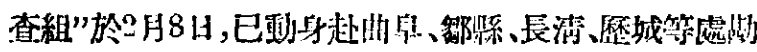
查。

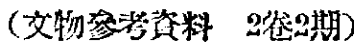

\section{1 河南文管會通過本年上半年 工作計劃}

河南省文物保管委暑會，於1950年8月20日成立,在

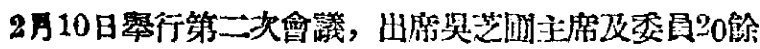

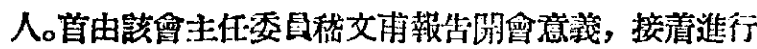

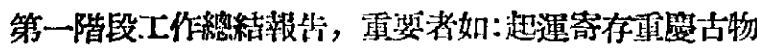

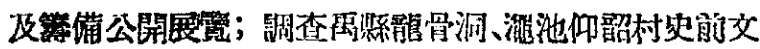
化遗址; 接收四野洛晹出士古物; 審查各縣名勝古頣報 告; 收集圖書古物;協助從猿到人展筧簿储;配合經沾建

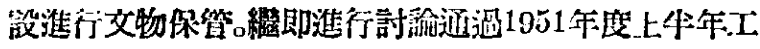

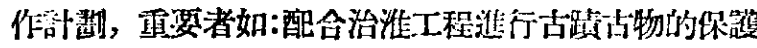

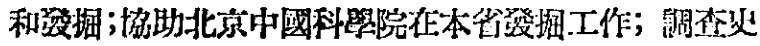

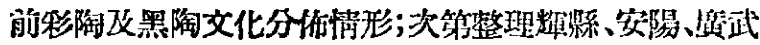

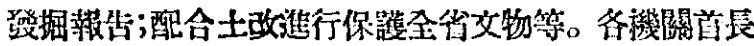

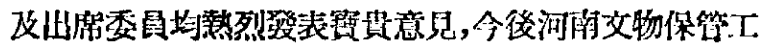
作，在人力物力䚺可條件下，将逐站恳開。

\section{（文物參考资料 2然2期)}

\section{2 河南渾池仰韶村附近古靕近况}

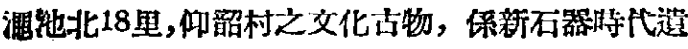

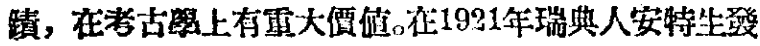
掘後(運走十餎大箱，編成西交報告，地賀學會毣山名

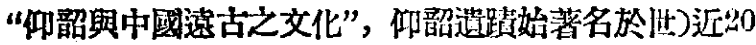
餘年，無人過問該古遗物，因多浮露地面，村中人多住昖

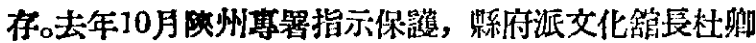

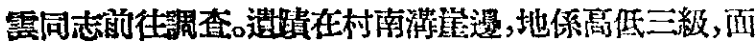

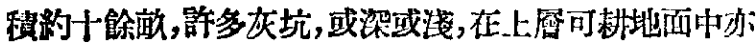

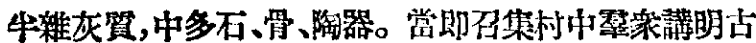

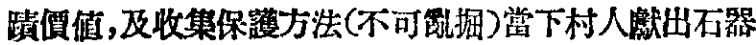

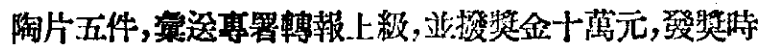

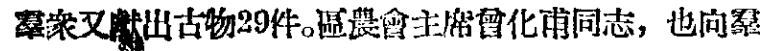

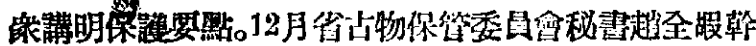

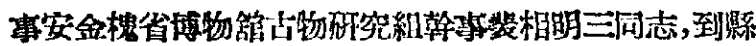

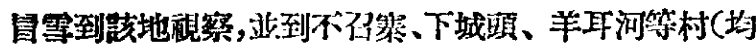

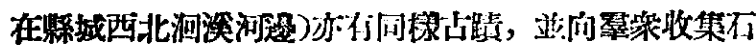

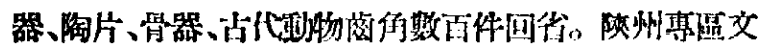

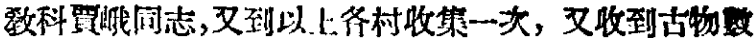

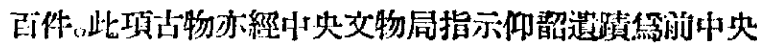

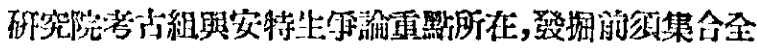

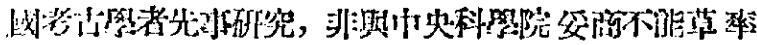

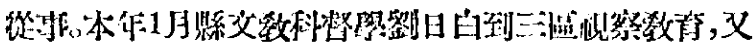

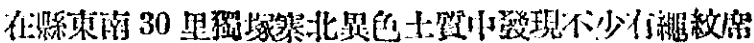

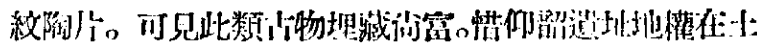

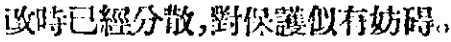

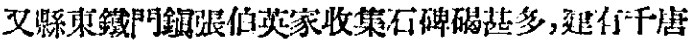

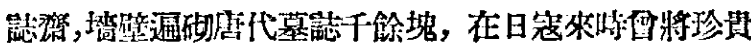

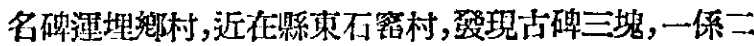

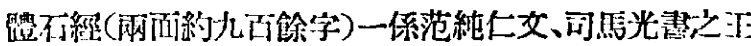

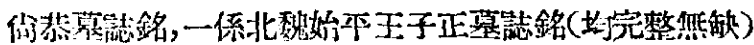

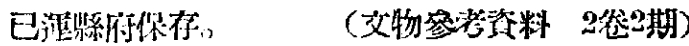

\section{3 列寧格勒大學東方系將以所 藏“永樂大典”運遗我國}

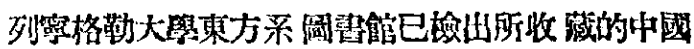

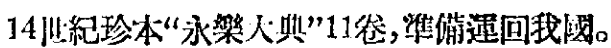

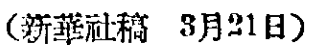

\section{4 廈門大學歷史柔教授林惠祥 將皘藏歷史古物標本全部獻 贈學校}

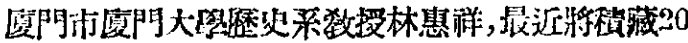

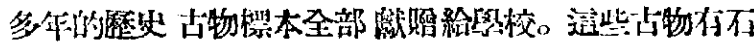

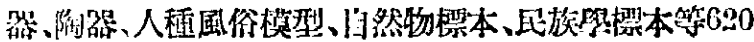

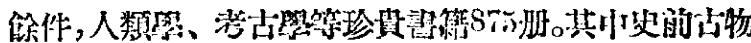

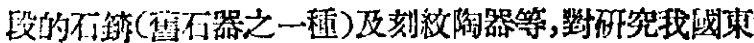

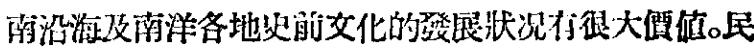

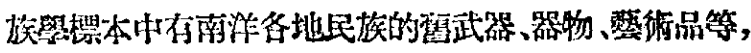

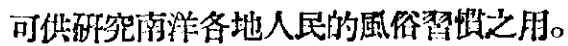

(新萧㪴稍 4月12日)

\section{5 語目研究所研究員陳士林 加中央西南訪問團}

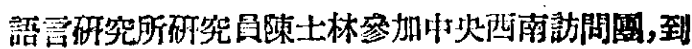

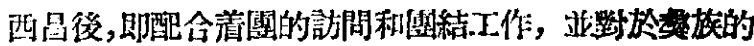

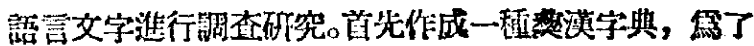

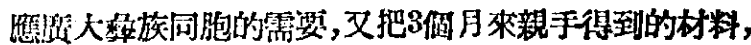

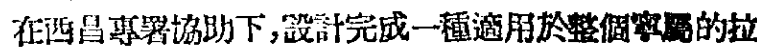

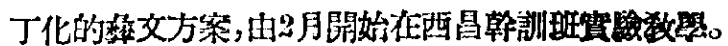

(本院工作閪報)

\section{6 第一次全國中等数育會䜅"}

第一次全國中等呚育會籍自3月19日開始殌過12天 的分組與大會討諭,已於3月31日朌利䦙幕。

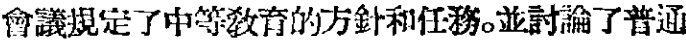

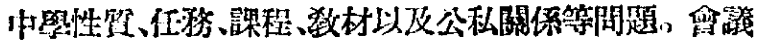

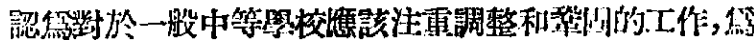

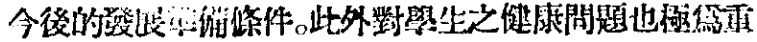




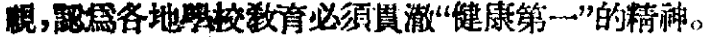

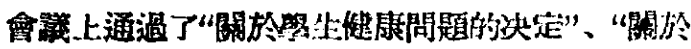

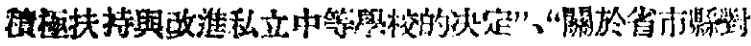

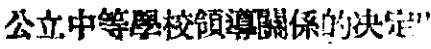

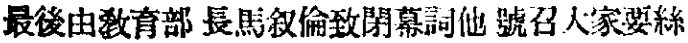

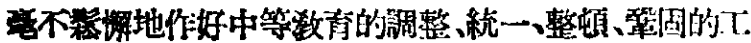

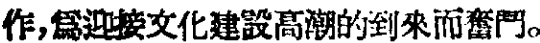

(新華社稿 4 月4日)

\section{7 零海少恢復蒙、藏、回、撒拉 等民族小學}

帮海省渦法一年中，已恢復蒙、藏、回、撒拉等:民族;

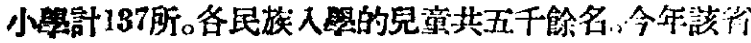

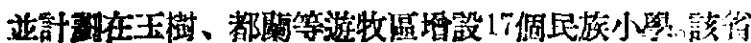

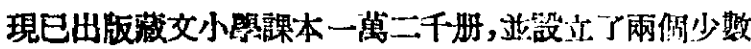
民族師資研究班。

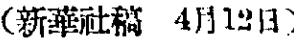

\section{8 山大萑大合併碢新的山東大學}

山東大罳和華東大學的合暗工作已絓元成。新的山東人

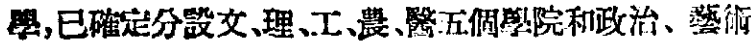

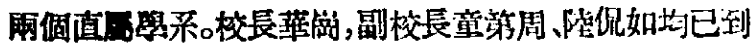

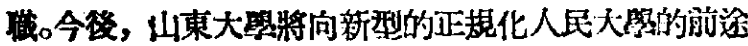
發展。

（交医啹 3月30日）

\section{科學界動態}

\section{9 全國科絔、科普號召科學工 作者進一步開展抗美援朝愛 國運動}

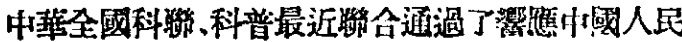

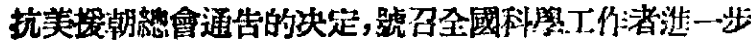
開展抗美援朝的墇大愛國運動力該决定稃：

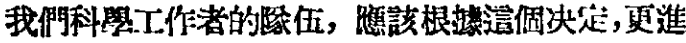

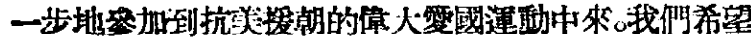

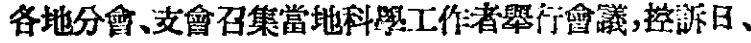

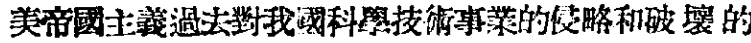

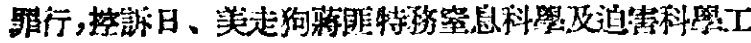

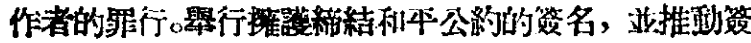

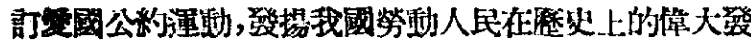
明和創造才能以及现在在各項建設.工作中的重荌成就,

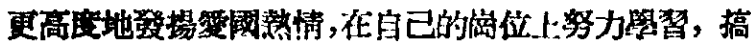
好工作。

(新華斻䅻 4月2日)

\section{0 上海科普協會全力展開講演 工作}

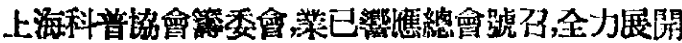

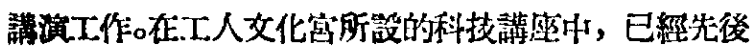

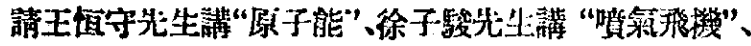

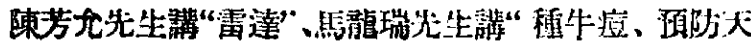

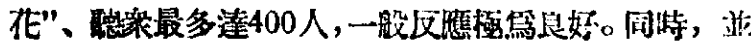

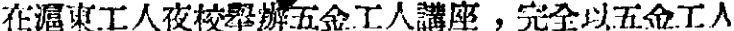

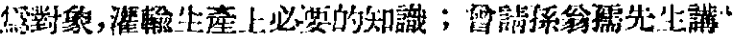

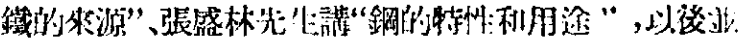

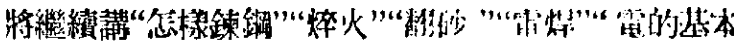

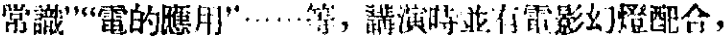

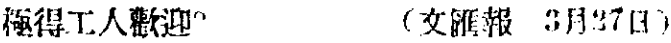

\section{1 浙江科聯等委會已成立}

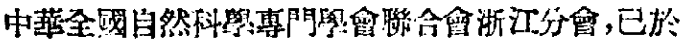

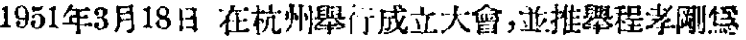

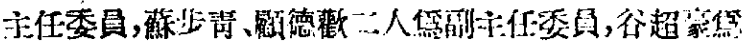
秘書處處長。

(㨨)

\section{2 蘭州科聯分會籌委會成立}

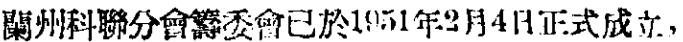

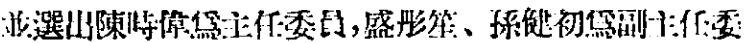

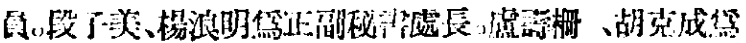

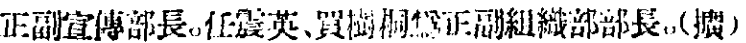

\section{3 皖北區科普籌委會成立}

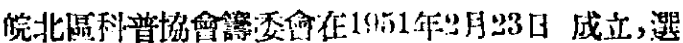

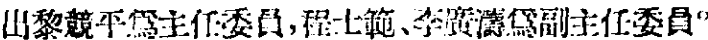

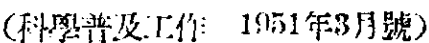

\section{4 察哈爾省和普籍委會成立}

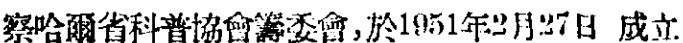

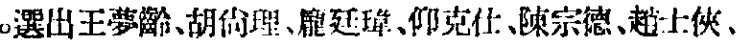

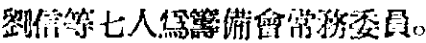

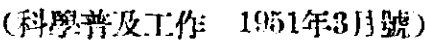

\section{5 河南省科蕾筑委合成立}

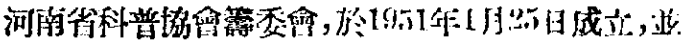

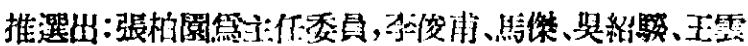

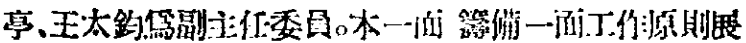
開.工作。（科罢普及:工们：1951年3月躆）

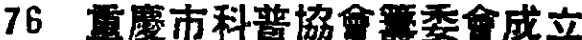

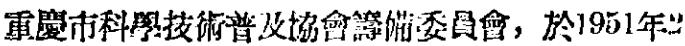

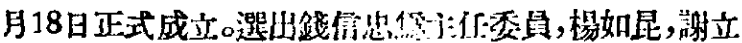

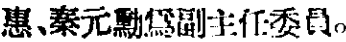

$$
\text { (武淡科興逝訊 No.11) }
$$

\section{7 川西區科普等委人選已決定}

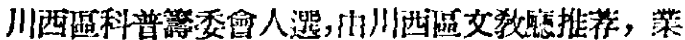

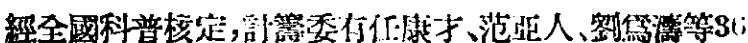
人。

(武淡科照通訊 No.11)

\section{8 㖄省科普篦委會成立}

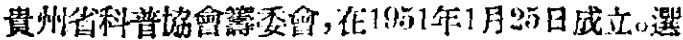

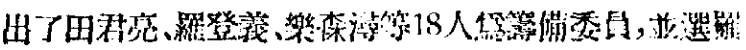

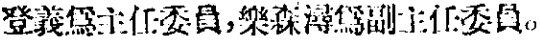

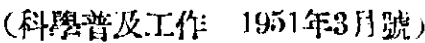




\section{9 我出席世界科學工作者協會 大會代表團抵布拉格}

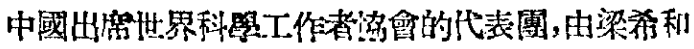

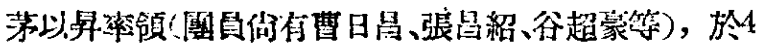
月3日抵達右拉格。他們在此等候法國發給入境签證, 即 前赴巴黎，出磨將於10日和11日舉行的世界科學工作者 㙝會第二国代表大會。 (人民日報 4 月6日)

\section{0 中國科學院成立心理研究所}

中國科照院心理研究所已正式成立，由政務院仁命 曹日昌临該所所長。

(握)

\section{1 中國科學院設立固害管}

中國科照院正式設立圖書舘，由陶孟和 争任該舘 長。

（嘱）

\section{2 中國科學院召集國際問題研 究座談會}

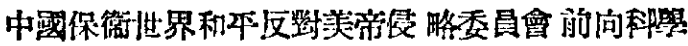

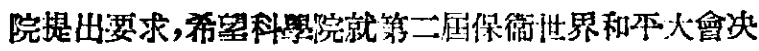

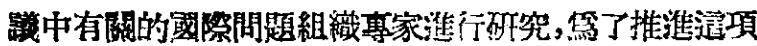
工作本院於3月9日由陶孟和副院長召集北大,清萿们院 內這一方面的專家座訬。會上除将和大所提出的問題分

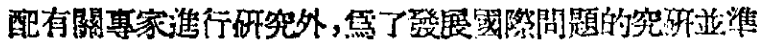

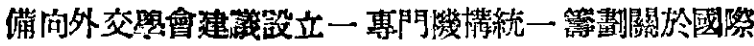
問題研究.工作: （中戓科照䟚院郝 No.1）

\section{3 郭沫若出席國際和平獎金委 員會會军返北京}

中國科累院院長、“加强國際和平”斯大林國祭獎金

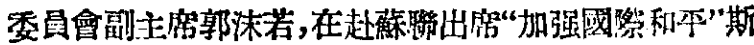

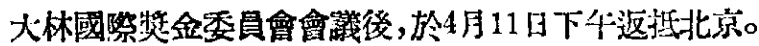

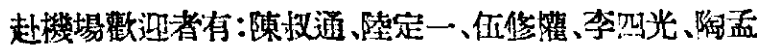

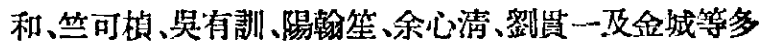
人。 （光明日瓣 4 月12日）

\section{4 出席印度學術會議我代表團 已返國}

中國科盟院㗹印度遗傳青種學會的邀請，淈辒物分

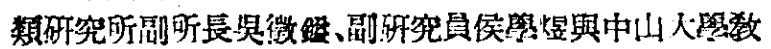

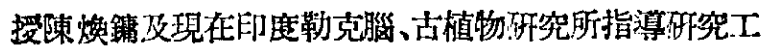

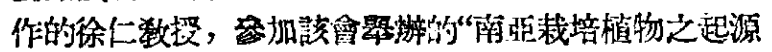
国分佈”討䄖會。吳、啲等代表於 1 月 3 日離京，12日 抵印宗德里。

會議盖雷討論印度電要栽培植物, 如稻、麥、棉.黃

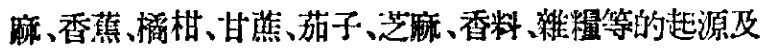

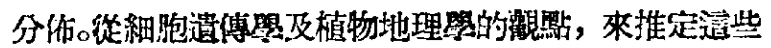
植物的分佈中心, 以便從分作中心引入視近種類, 淮行 新交,改良品種。

討論會歴持三日，會後代表們即赴全印各重要城市

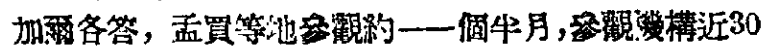

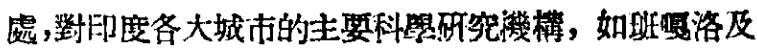

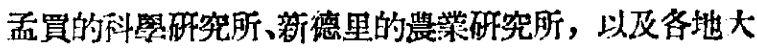

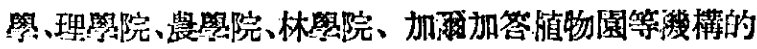

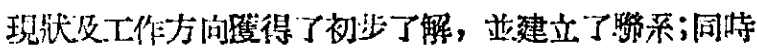

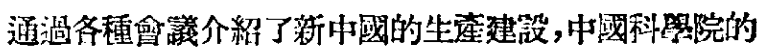
工工作方向和新中國科量研究工作的現狀, 給印度人民特

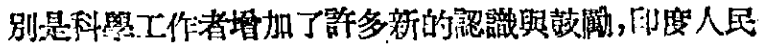

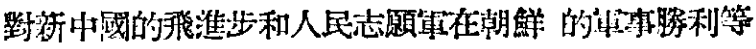

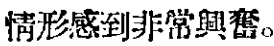

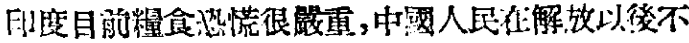

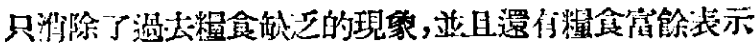
䉆奇和㙏慕。

证印度各地代表們受到印度人民熱烈徽迎與招待，

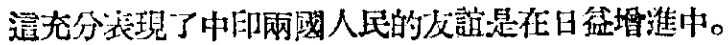

代表們於 3 月 2 日自印度首途返或，17日提京。

\section{5 中國科學院招待全國工業會 議代表}

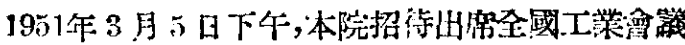

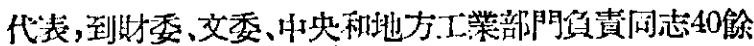

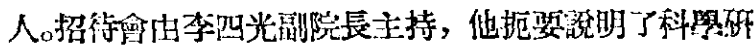

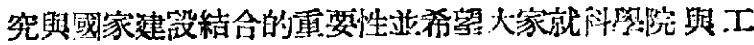

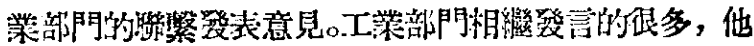

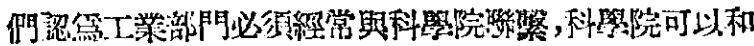

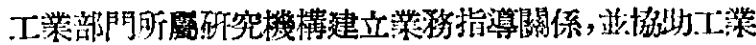

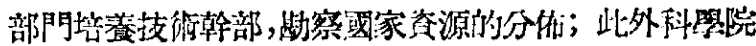

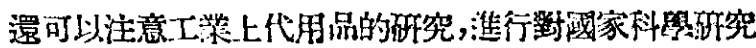
人才、涌書、毁俑的铜查工作。

$$
\text { （中國科照院院報 No.1） }
$$

\section{出版消息}

\section{6 新聞總署和出版總署弡出閶 於全國報紲期刊均應建立書 報評詒工作的指示}

新聞總署和出版總署於1951年 3 月 21 日發出閶於

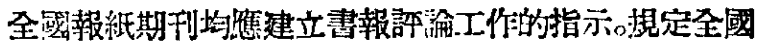

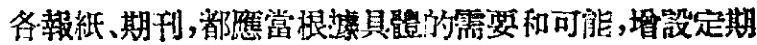

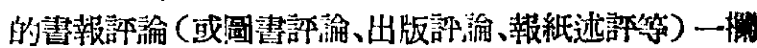

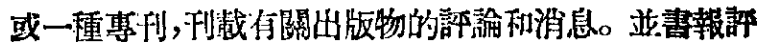

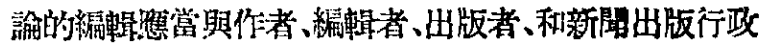

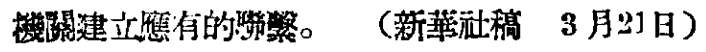

\section{7 “水杉”集已出版}

中國科照院沾決物研究所研究員斯行健所著的“水

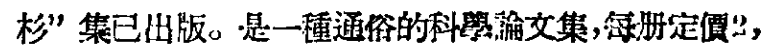
000元。科學院編譯局已代笉奇售。

\section{8 科學通報合訂本}

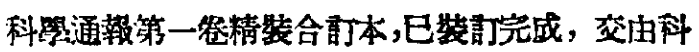


明院梮譯局墢售;每册定佰五萬元。

（擅）

\section{9 “自然科講座”將再版}

中國科照院出版的“自然科學講座”，分䉆謷學、物

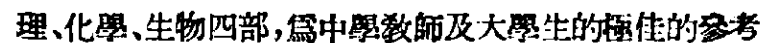

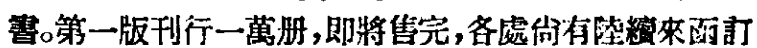
購,今已决定再版。

（㨨）

\section{國外之 部}

\section{自然科學}

\section{1 新式濨度測量器}

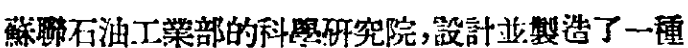

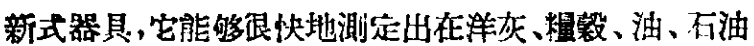

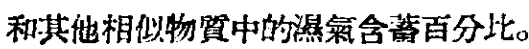

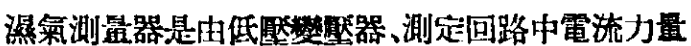

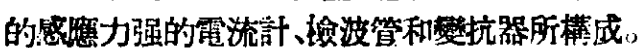

（東北中蘇友好 1951.3.21.）

\section{2 海底錄尞器的設計}

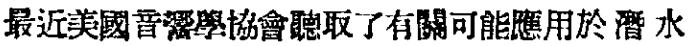
艇偵察的在液能中一储完全不同的錄晋方法。

人耳所不能聰見的超晋波撞整了水底要存多孔外

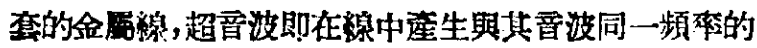

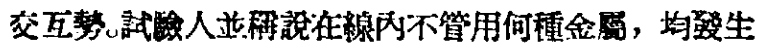
此種效能。

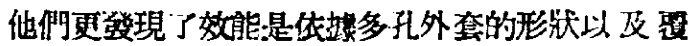
蓋金屚楾的溶液。露壓之發生或者是営線在水中, 或者

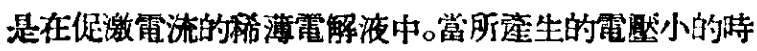

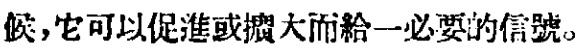

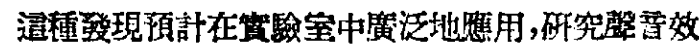

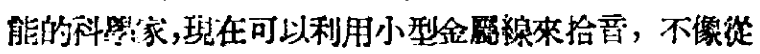

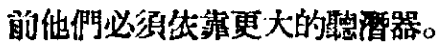

(Science News Lelter 1950.11.18.)

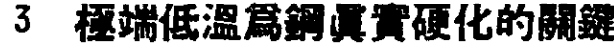

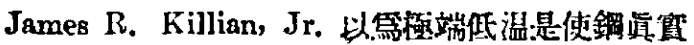

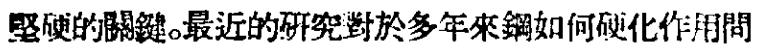
題已近於解决，同一研究也證明了過去的許多低温原理 的不可靠。

Killian 搏士曾於絕啮零度附近温域淮行低温的試

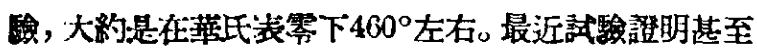

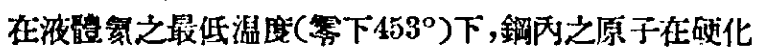
過程中,自己可重新䊀構。

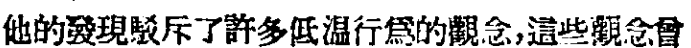

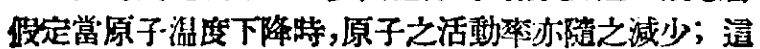
些踶念表示在柾低温度下所有原子活動狽告停止, 不發 止任何筫化。

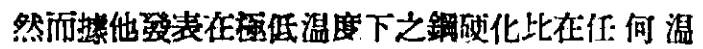
度下取来得到家。新研究指出龬之础化是一種集體的剪

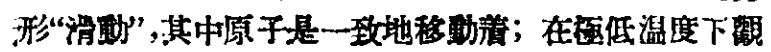

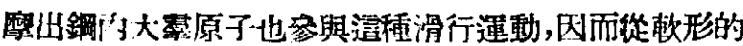
"Austenite" 致變成䨌破形的 "Martensite"。 (Science News Letter 1950.11.11.)

\section{4 光速度}

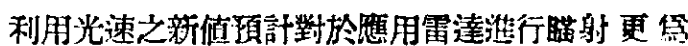
準確。每秒299, 789.3公尺的新德(每秒約 186,28 ) 公里) 比普通公涊数字每秒鐘約快 13 公尺, Stanford 的数察

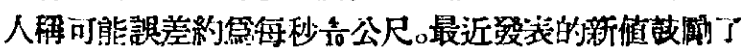

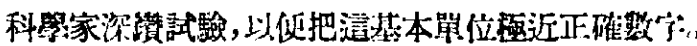

利用可兄光潐行的許多光速的湘量，每一路测是普

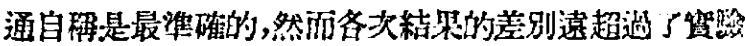
者所定的限度。

用無缐電波測量雷達在二物間住返所需時閌即可 决定它的距離，無線電波與光波的湿別只在它們的波

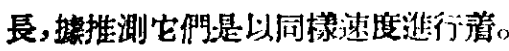

最近科祭家測量了然称雪没检驗光速，他們的結果

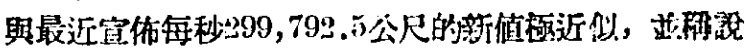
富個數字的可渄誤差的每秒三公尺左有。

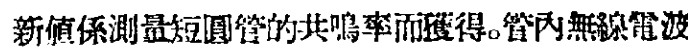

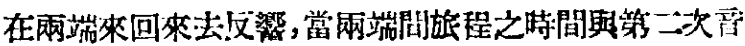

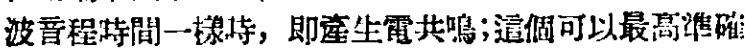
度梁測出來。

$$
\text { (Science News Ietter 1950.11.18) }
$$

\section{5 居結氣流動力}

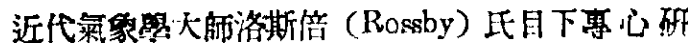

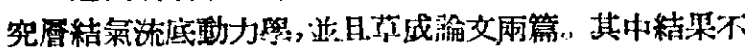

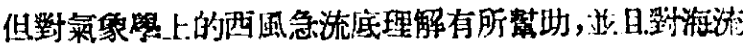
權浩特别重要。

（潮）

\section{6 兩度斜壓大氣数値預報問題}

普林斯顿高等矿究所在研究員却尼 (Chamey) 解

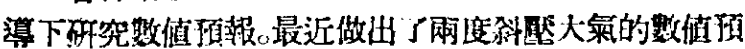

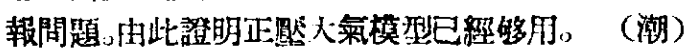

\section{Balsa 木粉弉示氣流式荄}

敗木 balsa 的木粉米，正被用來作有關氮流的訌酸。

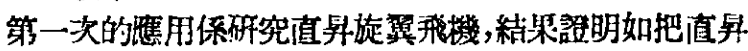

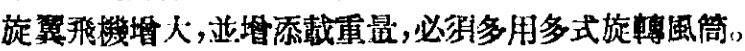

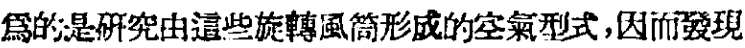
了所謂 NACA balsa粉米的技衡。根据最近 NACA 的

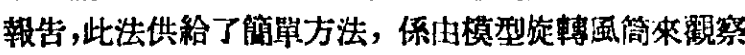
氣流的分佈，並上適合嫶用於在一定面上氣流型式圆表 